\title{
Tobacco control achievements and priority areas in the WHO Europe Region: A review
}

\author{
Andrea Glahn', Christina N. Kyriakos', Cornel Radu Loghin', Dominick Nguyen' , Polina Starchenko', Carlos Jimenez- \\ Ruiz ${ }^{2,3}$, Marine Faure ${ }^{3}$, Brian Ward ${ }^{3}$
}

\begin{abstract}
INTRODUCTION Tobacco control efforts have been advancing globally, including the adoption and entry into force of the World Health Organization (WHO) Framework Convention of Tobacco Control (FCTC), as well as the adoption of the European Union EU Tobacco Products Directive. With the present review, the European Network for Smoking and Tobacco Prevention (ENSP) and European Respiratory Society (ERS) aim to provide a comprehensive overview on the status of WHO FCTC implementation, policy achievements and priority areas across countries in the WHO Europe Region.

METHODS The review was conducted through a triangulation of data extracted from a survey administered to ENSP members, the WHO FCTG Implementation Database, Tobacco Control Laws and the Tobacco Control Scale 2016.

RESULTS Using the WHO MPOWER measures as a framework, we report on the implementation status of nine FCTC articles across 47 countries in the WHO Europe Region. The average number of articles fully implemented was 3.58. FCTC articles least fully implemented were: Article 5.3 on Tobacco Industry Interference $(25.5 \%, \mathrm{n}=12)$, Article 20 on Research $(34.0 \%, \mathrm{n}=16)$, and Article 15 on Illicit trade $(40.4 \%, \mathrm{n}=19)$. The most commonly fully implemented articles were: Article 8 on Smoke-free legislation $(63.8 \%, \mathrm{n}=30)$, Article 16 on Underage sales $(57.4 \%, \mathrm{n}=27)$, and Article 6 on Price and tax measures $(51.2 \%, \mathrm{n}=24)$. Policy achievements and recommended priority areas for future national tobacco control activities varied greatly among countries.

CONCLUSIONS Findings highlight the multitude of successes in tobacco control efforts across the region in recent years, but point out the need to address gaps in FCTC implementation.
\end{abstract}

\author{
AFFILIATION \\ 1 European Network for \\ Smoking and Tobacco \\ Prevention, Brussels \\ Belgium \\ 2 Smoking Cessation Service of \\ Region Madrid, Spain \\ 3 European Respiratory Society, \\ Lausanne, Switzerland \\ CORRESPONDENCE TO \\ Christina N. Kyriakos. European \\ Network for Smoking and \\ Tobacco Prevention, Chaussee \\ d'Ixelles 144, 1050 Brussels, \\ Belgium. \\ E-mail: ckyriakos@tobcontrol.eu

\section{KEYWORDS} \\ Framework Convention on \\ Tobacco Control, WHO FCTC, \\ TPD, Tobacco Products Directive, \\ Implementation status, WHO \\ Europe
}

Received: 6 March2018 Revised: 28 March 2018 Accepted: 13 April 2018

\section{INTRODUCTION}

The tobacco epidemic is responsible for the death of 700000 European citizens every year. Compared to the rest of the world, the WHO European Region has one of the highest proportions of deaths attributable to tobacco. Tobacco control efforts have been advancing globally, including the adoption and entry into force of the WHO Framework Convention of Tobacco Control (WHO FCTC), as well as the adoption of the European Union (EU)
Tobacco Products Directive (2014/40/EU) (TPD). With these tools, governments are equipped with evidence-based strategies for reducing the burden of tobacco-related morbidity and mortality, through comprehensive tobacco control legislation.

The WHO FCTC was adopted by the World Health Assembly on 21 May 2003 and entered into force on 27 February 2005 as the first global public health treaty. As of March 2017, 180 parties worldwide have ratified the FCTC, among them the EU, binding 
them under international law to fulfil the treaty provisions, through implementation of policies aimed at reducing the supply and demand of tobacco products $^{5}$. The WHO FCTC was conceived out of the notion that the tobacco epidemic is a globalized issue that requires international cooperation and ultimately the treaty 'reaffirms the right of all people to the highest standard of health ${ }^{3}$. To facilitate country-level adoption and implementation of the WHO FCTC by the Parties, the WHO has developed specific Article implementation guidelines and has also created the MPOWER technical assistance package, which contains measures for monitoring FCTC progress to effectively manage and improve its implementation.

The Tobacco Products Directive (2014/40/ EU) (TPD), which entered into force on 19 May 2014 and became applicable in EU Member States (MS) on 20 May 2016 strengthens regulation around the manufacturing, presentation and sale of tobacco products in the EU ${ }^{4}$. The revised TPD, which replaces the 2001 Directive, was developed in response to the emergence of new scientific evidence around effective tobacco control measures, new tobacco products entering the market, as well as the EU's ratification of the WHO FCTC in 2005. Key provisions of the TPD include but not limited to: requirements around packaging and labelling, reporting tobacco product ingredient, electronic cigarettes, as well as prohibiting characterising flavours in cigarettes and roll-your-own tobacco, banning promotional and misleading elements on tobacco products, and tracking and tracing measures to combat illicit trade ${ }^{4}$. The TPD thereby effectively aims to maximize health protection and consumer awareness among EU citizens.

Challenges to the implementation of both the WHO FCTC and EU TPD remain in a number of EU and non-EU MS. Two European organizations are working to mitigate some of these implementation challenges by coupling tobacco control advocacy with collaboration across Europe and globally. The European Network for Smoking and Tobacco Prevention (ENSP) is an international non-profit organisation active in coordinated actions in tobacco control, created in 1997 under Belgium law (identification number 16377/97) ${ }^{9}$. ENSP represents a large network of healthcare professionals, academics, researchers and experts, and supports its members in their involvement with implementation of the WHO FCTC and transposition of the TPD into national laws. The European Respiratory Society (ERS) is an international organisation of healthcare professionals, scientists and other experts working in respiratory medicine. The ERS Brussels office works closely with decision-making authorities at International, EU and National levels to raise awareness of tobacco-related diseases and promote the adoption and implementation of tobacco control policies.

In the present review, ENSP and ERS aim to identify the status of implementation of the WHO FCTC across the WHO Europe Region, and TPD among EU MS using the WHO MPOWER measures as a framework. The six components of MPOWER are: 1) Monitor tobacco use and prevention policies; 2) Protect people from tobacco smoke; 3) Offer help to quit tobacco use; 4) Warn about the dangers of tobacco; 5) Enforce bans on tobacco advertising, promotion and sponsorship; and 6) Raise taxes on tobacco $^{7}$. Furthermore, the review highlights the primary policy achievements in tobacco control in recent years, as well as identifies country-specific priority areas of policy interventions, ultimately aimed at decreasing the demand for tobacco and improving measures of tobacco-dependence treatment.

\section{METHODS}

\section{Review procedure}

We reviewed various data sources, including the WHO FCTC Implementation Database, as well as conducted a survey administered to ENSP members in order to compile a comprehensive overview of the state of FCTC and TPD implementation in the WHO Europe region. Specifically, reviews for each country within the WHO Europe Region were carried out to gather information on the following areas: 1) Relevant legislation in tobacco control and recent legislative achievements; 2) Achievements in tobacco control interventions following the MPOWER framework, specific articles of the TPD and specific articles of the WHO FCTC; and 3) Identification of priority areas in future national tobacco control activity also based on the MPOWER framework. 


\section{Data sources}

\section{WHO FCTC Implementation Database}

As part of FCTC obligations of the Parties, Article 21 requires the submission of periodic reports on implementation progress to the Conference of the Parties (COP) and through the Convention Secretariat $^{3}$.. As of 2012, reports are to be submitted in intervals of two years and are synchronised with the biennial cycle of the $\mathrm{COP}^{11}$. The reporting instrument of the WHO FCTC by the Parties entails a mandatory core questionnaire, as well as a voluntary additional questionnaire on use of the WHO FCTC implementation guidelines. The WHO has made these reports available through a web-based database where implementation of FCTC articles and measures can be searched both by specific Treaty Provisions and by individual Parties ${ }^{10}$. The questionnaires themselves, along with supplemental resource materials developed by the WHO contain reporting instructions in order to standardise and ensure the highest quality of data from Parties. Additionally, the WHO FCTC Implementation Database contains country-specific 'WHO Tobacco Control Fact Sheets', which in addition to providing data on smoking prevalence and model-projected impact of tobacco control policies, also contains information on key policies and legislative actions around tobacco control as they relate to the WHO MPOWER framework ${ }^{10}$.

Tobacco Control Laws, International Legal Consortium of the Campaign for Tobacco-Free Kids

Tobacco Control Laws is a project of the International Legal Consortium of the Campaign for Tobacco-Free Kids that contains a depository of tobacco control laws, legislative reviews and policy fact sheets from across the globe. Analyses on tobacco control legislation and litigation are conducted by legal advisors at the International Legal Consortium in collaboration with in-country lawyers. The present review has made use of resources gathered under the section 'Tobacco Control Laws - Legislation', which provides comprehensive information on the main legal achievements in tobacco control of the country, and the degree to which legislation complies with the WHO FCTC and its associated Guidelines ${ }^{15}$. Specifically, the reviews focus on FCTC Article 8 (Smoke-Free Places), Article 11 (Tobacco Packaging and Labelling), and Article 13 (Tobacco Advertising, Promotion and Sponsorship). The protocols and review templates on how specific legal measures were analysed are further available on the Tobacco Control Laws website ${ }^{15}$.

\section{ENSP Members' Survey}

From 27 November - 22 December 2016, the ENSP Secretariat carried out a survey on the status of implementation of the WHO FCTC, and where applicable the TPD, in multiple European countries and administered through a web-based questionnaire to ENSP members. ENSP members consist of representatives from national coalitions, organisations, academics and individuals active in tobacco control across 34 countries in the WHO Europe Region. The questionnaire comprised 10 questions assessing the degree of national implementation of the provisions of the WHO FCTC, and in cases of EU MS of the TPD. The survey also captured information on the involvement and support of ENSP in these areas. ENSP members were chosen as a reliable source of information on both TPD and WHO FCTC implementation and stakeholder involvement, due to their history of activity and knowledge about national tobacco control legislation and advocacy actions in their specific countries. Data from the survey were used to inform the identification of tobacco control priority areas offered in this review and also cross-referenced with the FCTC Implementation Database to report on the status of FCTC implementation for specific Articles by country.

\section{Tobacco Control Scale in Europe 2016}

The Tobacco Control Scale in Europe Report 2016 describes the results of a survey on tobacco control activities carried out in 35 European countries, based on Joossens \& Raw's Tobacco Control Scale (2006). The scale quantifies the implementation of tobacco control policies at the country level, based on six main policies: 1) Price increases through higher taxes on cigarettes and other tobacco products; 2 ) Bans/restrictions on smoking in public and work places; 3) Better consumer information, including public information campaigns, media coverage, and publicising research findings; 4) Comprehensive bans on the advertising and promotion of all tobacco 
products, logos and brand names; 5) Large, direct health warning labels on cigarette boxes and other tobacco products; and 6) Treatment to help dependent-smokers to stop, including increased access to medications ${ }^{18}$. The 2016 survey data refer to legislation in force on 1 January 2017, price data on 1 July 2016, and the tobacco control budget in $2015^{17}$.

\section{Analysis}

Data from the various sources were triangulated to categorise WHO Europe Region countries as either having implemented, partial implemented, or not implemented the respective FCTC articles. Furthermore, based FCTC implementation status and recent tobacco control policy achievements, ENSP and ERS identified priority areas and recommendations for improved tobacco control for each country.

\section{RESULTS}

Nine FCTC articles were identified as relevant in relation to the MPOWER framework and were reviewed on their degree of implementation among 47 countries in the WHO Europe Region, as presented in Table 1. WHO FCTC measures that have been the least fully implemented among the 47 countries surveyed include: Article 5.3 on Tobacco Industry Interference $(25.5 \%, \mathrm{n}=12)$, Article 20 on

Table 1. Overview of the FCTC implementation status for articles relevant to the MPOWER framework in a selection of WHO Europe Region countries

\begin{tabular}{|c|c|c|c|c|c|c|c|c|c|c|}
\hline Country & $\begin{array}{l}\text { Article } 5.3 \\
\text { Tobacco } \\
\text { industry } \\
\text { interference }\end{array}$ & $\begin{array}{l}\text { Article } \\
6 \text { Price } \\
\text { and tax } \\
\text { measures }\end{array}$ & $\begin{array}{l}\text { Article } 8 \\
\text { Smoke free } \\
\text { legislation }\end{array}$ & $\begin{array}{l}\text { Article } 12 \\
\text { Education, } \\
\text { communication } \\
\text { and public } \\
\text { awareness }\end{array}$ & $\begin{array}{l}\text { Article } 13 \\
\text { Tobacco } \\
\text { advertising } \\
\text { sponsorship }\end{array}$ & $\begin{array}{l}\text { Article } 14 \\
\text { Tobaceo } \\
\text { dependency } \\
\text { and cessation }\end{array}$ & $\begin{array}{l}\text { Irticle } 15 \\
\text { Illicit trade }\end{array}$ & $\begin{array}{l}\text { Article } 16 \\
\text { Underage } \\
\text { sales }\end{array}$ & $\begin{array}{l}\text { Article } 20 \\
\text { Rescarch }\end{array}$ & $\begin{array}{l}\text { Number of } \\
\text { Articles fully } \\
\text { implemented }\end{array}$ \\
\hline Albania & Yes & Yes & Yes & Yes & Partly & Partly & Partly & Partly & Partly & 4 \\
\hline Armenia* & Partly & No & Partly & Partly & Partly & No & No & Yes & No & 1 \\
\hline Austria & Partly & Partly & Partly & Partly & Partly & Partly & Yes & Partly & Yes & 2 \\
\hline Azerbaijan & No & No & No & Partly & No & Partly & Partly & Partly & No & 0 \\
\hline Belarus & No & Yes & Yes & Yes & Yes & Yes & Partly & Yes & Yes & 7 \\
\hline Belgium & No & Yes & Yes & Yes & Yes & Yes & Partly & Yes & Yes & 7 \\
\hline $\begin{array}{l}\text { Bosnia \&t } \\
\text { Herzegovina }\end{array}$ & No & No & Partly & Partly & Partly & Partly & Yes & Yes & Yes & 3 \\
\hline Bulgaria & - & Yes & Yes & Partly & Partly & Partly & Yes & Yes & Partly & 4 \\
\hline Croatia & Yes & Yes & Yes & Yes & Yes & Yes & Yes & Yes & Yes & 9 \\
\hline Cyprus & Yes & Partly & Yes & Yes & Partly & Yes & Yes & Partly & No & 5 \\
\hline $\begin{array}{l}\text { Czech } \\
\text { Republic }\end{array}$ & Partly & No & Partly & Yes & Partly & Yes & No & Yes & Yes & 4 \\
\hline Denmark $^{*}$ & No & Yes & Yes & Partly & Partly & Yes & - & Partly & Yes & 4 \\
\hline Estonia & Partly & Partly & Yes & Yes & Yes & Yes & Yes & Partly & & 4 \\
\hline Finland & Yes & Yes & Yes & Yes & Yes & Yes & Yes & Yes & Yes & 9 \\
\hline France $^{*}$ & Yes & Yes & Yes & Yes & Yes & Yes & Yes & Yes & Yes & 9 \\
\hline Georgia & No & Yes & Partly & Partly & Partly & No & No & - & Partly & 1 \\
\hline Germany & Partly & Partly & Partly & Partly & No & No & No & Yes & Partly & 1 \\
\hline Greece & No & No & Yes & Partly & Partly & No & No & Yes & No & 1 \\
\hline Hungary* & Yes & Yes & Yes & Yes & Yes & Yes & Yes & Yes & No & 7 \\
\hline Iceland & Partly & Yes & Yes & Partly & Partly & Partly & No & Yes & Partly & 3 \\
\hline Ireland & - & Yes & Yes & Yes & Yes & Yes & Yes & Yes & Yes & 8 \\
\hline Israel & No & Yes & Yes & No & No & Yes & Partly & Yes & No & 4 \\
\hline Italy & No & Partly & Yes & Partly & Partly & Partly & Yes & Partly & Partly & 2 \\
\hline Kazakhstan & No & Partly & Yes & Partly & Partly & Partly & Yes & Partly & Partly & 2 \\
\hline Latvia & No & Partly & Yes & No & Partly & Partly & Yes & Yes & Partly & 3 \\
\hline Lithuania & Yes & Yes & Yes & Yes & Yes & Yes & Yes & Yes & - & 8 \\
\hline Luxembourg & Yes & Partly & Yes & Partly & No & Partly & Partly & Yes & Partly & 3 \\
\hline Malta & Yes & Partly & Yes & Partly & Yes & Partly & Yes & Yes & Yes & 3 \\
\hline
\end{tabular}


Table 1. Continued

\begin{tabular}{|c|c|c|c|c|c|c|c|c|c|c|}
\hline Country & $\begin{array}{l}\text { Article } 5.3 \\
\text { Tobacco } \\
\text { industry } \\
\text { interference }\end{array}$ & $\begin{array}{l}\text { Article } \\
6 \text { Price } \\
\text { and tax } \\
\text { measures }\end{array}$ & $\begin{array}{l}\text { Article } 8 \\
\text { Smoke free } \\
\text { legislation }\end{array}$ & $\begin{array}{l}\text { Irticle } 12 \\
\text { Education, } \\
\text { communication } \\
\text { and public } \\
\text { awareness }\end{array}$ & $\begin{array}{l}\text { Article } 13 \\
\text { Tobaceo } \\
\text { advertising } \\
\text { sponsorship }\end{array}$ & $\begin{array}{l}\text { Article } 14 \\
\text { Tobacco } \\
\text { dependency } \\
\text { and cessation }\end{array}$ & $\begin{array}{l}\text { Irticle } 15 \\
\text { Illicit trade }\end{array}$ & $\begin{array}{l}\text { Irticle } 16 \\
\text { Underage } \\
\text { sales }\end{array}$ & $\begin{array}{l}\text { Article } 20 \\
\text { Research }\end{array}$ & $\begin{array}{l}\text { Vumber of } \\
\text { Articles finly } \\
\text { implemented }\end{array}$ \\
\hline $\begin{array}{l}\text { Republic of } \\
\text { Moldova* }^{*}\end{array}$ & Yes & Yes & Yes & Yes & Yes & Partly & No & Yes & Partly & 6 \\
\hline Netherlands* & Yes & Partly & Yes & Yes & Yes & Yes & Partly & Yes & Yes & 6 \\
\hline Norway & No & Yes & Yes & Yes & Yes & Yes & Partly & Yes & Yes & 7 \\
\hline Poland* & Partly & Partly & Partly & Partly & Yes & Yes & Yes & Yes & Partly & 7 \\
\hline Portugal* & Partly & Yes & Yes & Yes & Yes & Yes & Yes & Yes & Yes & 4 \\
\hline Romania* & No & Yes & Yes & Yes & No & Yes & Yes & No & No & 7 \\
\hline Serbia & Yes & Partly & Yes & Partly & Yes & Partly & Partly & Yes & Partly & 5 \\
\hline Slovakia & Partly & Yes & Partly & Partly & Partly & No & Yes & Partly & No & 4 \\
\hline Slovenia* & Partly & Yes & Yes & Yes & Yes & Yes & Partly & Yes & Yes & 2 \\
\hline Spain & No & No & Yes & No & No & Partly & No & No & No & 7 \\
\hline Sweden & No & Yes & Yes & Partly & Yes & Yes & Partly & Yes & Yes & 1 \\
\hline Switzerland & - & Yes & Partly & Partly & Partly & Partly & - & - & - & 1 \\
\hline Tajikistan & - & Partly & No & No & Partly & No & - & - & - & 0 \\
\hline $\begin{array}{l}\text { The former } \\
\text { Yugoslav } \\
\text { Republic of } \\
\text { Macedonia } \\
\text { (FYROM) }\end{array}$ & - & Partly & Partly & Partly & Partly & Partly & - & - & - & 0 \\
\hline Turkey & - & Yes & Partly & Yes & Partly & Partly & - & - & - & 2 \\
\hline Turkmenistan & - & Partly & Partly & Yes & Partly & Yes & - & - & - & 2 \\
\hline Ukraine & - & Partly & Partly & Yes & Partly & Yes & - & - & - & 2 \\
\hline $\begin{array}{l}\text { United } \\
\text { Kingdom } \\
\text { of Great } \\
\text { Britain and } \\
\text { Northern } \\
\text { Ireland }\end{array}$ & - & Yes & Yes & Yes & Yes & Partly & - & - & - & 4 \\
\hline Uzbekistan & - & - & Partly & Partly & Partly & Partly & - & - & - & 0 \\
\hline \multicolumn{11}{|c|}{$\begin{array}{l}\text { - Insufficient data available, * Sources: All country reviews of FCTC Implementation are based on the WHO FCTC Implementation Database (http://apps.who.int/fctc/ } \\
\text { implementation/database), while some are supplemented with information from the following organisations: } \\
\text { Armenia: Gerald and Patricia Turpanjian School of Public Health, Denmark: Danish Cancer Society, France: Paris Sans Tabac, Les Droits des Non-Fumeurs, Hungary: Health } \\
\text { Promotion Focal Point for Tobacco Control, Republic of Moldova: Center for Health Policies and Studies, Moldova, Netherlands: Alliantie Nederland Rookvrij (Dutch Alliance } \\
\text { for a Smoke-free Society), Poland: Foundation Smart Health - Health in 3D, Portugal: Portuguese Coalition for Tobacco Prevention, Romania: Romanian Forum of Prevention, } \\
\text { Romanian Society of Pneumology, Slovenia: Slovenian Coalition for Public Health, Environment and Tobacco Control, No Excuse Slovenia }\end{array}$} \\
\hline
\end{tabular}

Research $(34.0 \%, \mathrm{n}=16)$, and Article 15 on Illicit trade $(40.4 \%, \mathrm{n}=19)$. The most commonly fully implemented measures of the WHO FCTC include: Article 8 on Smoke-free legislation $(63.8 \%, \mathrm{n}=30)$, Article 16 on Underage sales $(57.4 \%, \mathrm{n}=27)$, and Article 6 on Price and Tax measures $(51.2 \%, \mathrm{n}=24)$.

The average number of articles fully implemented across the 47 countries, was 3.58 (out of nine). The countries with the lowest number of WHO FCTC articles adopted and/or fully implemented are Azerbaijan, FYROM, Tajikistan, Uzbekistan (0/9 measures), Armenia, Georgia, Germany, Greece,
Spain and Switzerland (1/9 measures) and Austria, Italy, Kazakhstan, Slovakia, Turkey, Turkmenistan and Ukraine (2/9 measures). The countries with the highest number of articles fully implemented are Croatia, Finland and France (9/9 measures implemented), as well as Ireland and Lithuania (8/9 measures implemented) (Table 1).

In Table 2, we highlight the recent achievements in tobacco control policy implementation and subsequently identified priority areas for each country. The majority of countries had recent achievements in tobacco control to report on. Some 
common areas of achievements included amended or adopted regulations on product packaging and labelling, sale of electronic cigarettes, smoke-free policies in public places, increases in tobacco taxes, and restrictions in advertising of tobacco products. Among EU MS, many achievements centred around the transposition of the TPD into national law, with changes to tobacco products including, but not limited to larger and mandatory graphic health warnings, ability to regulate cross-border distance sales, safety and quality requirements for electronic cigarettes, and mandatory electronic reporting on tobacco product ingredient by manufacturers.

Recommended priority areas for future national tobacco control activities varied greatly among countries, depending on the respective countries' degree of FCTC implementation (Table 2). For instance, in countries lacking comprehensive indoor smoking bans, priority areas focus on expanding smoke-free legislation to other realms, such as public transport, workplaces and private cars. In other countries where all enclosed public places are completely smoke-free, efforts are encouraged to focus on dedicating funds for enforcement, having a system in place for citizen complaints and further investigations, as well as fining both the patron and establishment for smoking violations. Similarly, in countries where health warnings are only in text and/or do not fully describe the harmful effects of tobacco use on health, and cover only a small percentage of packaging, it is recommended that measures be taken to implement graphic or pictorial cigarette warnings that cover at least $65 \%$ of the front and back of packaging. On the other hand, in countries that already mandate graphic or pictorial health warnings on cigarettes and roll-your-own tobacco products, as well as other packaging parameters, most notably as specified by the TPD, adoption of plain packaging is encouraged as the next priority. Other priority areas that were identified across many countries include: raising taxes on tobacco, implementing and enforcing bans on tobacco advertising, promotion and sponsorship, combating illicit trade, decreasing tobacco industry interference, and making cessation services available and covering costs of smoking cessation pharmacotherapy, such as Nicotine Replacement Therapy.

\section{DISCUSSION}

Full implementation of key articles of the WHO FCTC is associated with increased reduction in smoking prevalence -. As such, maximizing implementation is critical to combatting the pervasive global tobacco epidemic and the burden of non-communicable diseases. Through a triangulation of information from various data sources, the current review presents the state of FCTC implementation across 47 countries in the WHO Europe Region in 2016. It further highlights recent achievements in national tobacco control efforts across the region. Lastly, the review offers country-level stakeholders in tobacco control with a tailored list of action areas for effectively decreasing tobacco consumption in their country.

The extensive list of newly adopted tobacco control laws, policies and decrees that were identified supports recent-trends data on increased FCTC across countries that have ratified the treaty ${ }^{20}$. However, while many countries have fully implemented most or all of the nine articles, four countries have not fully implemented any of the articles (Azerbaijan, Tajikistan, FYROM, and Uzbekistan). Vast challenges to FCTC implementation exist, with tobacco industry interference suggested to be a main factor in undermining tobacco control progress, particularly for lower and middle-income countries, and therefore may explain country differences -. This is a concern, given that Article 5.3 that aims to combat tobacco industry interference was the least fully implemented article among countries. It is promising, however, that other articles such as Article 8 on smoke-free legislation, have been shown to be effective in reducing smoking prevalence. The considerable variation in the degree of FCTC article implementation across the WHO Europe Region calls for future research to focus on reducing such disparities ${ }^{20}$.

ENSP and ERS encourage respective country leadership and stakeholders to prioritise adoption and implementation of the articles least frequently implemented (Articles 5.3, 20 and 15) and to ensure full implementation of the articles most commonly implemented (Articles 8, 16 and 6).

\section{Strengths and limitations}

The limitations of this review should be noted. While data from multiple sources using rigorous methods 
were triangulated, systematic review methods were not used. Despite the expertise and knowledge among ENSP members completing the survey, answers may be subject to a variation in the level of detailed knowledge. Where some ENSP members work more closely with the TPD, others work more with implementation of the FCTC or vice versa, while others again may be more focused on non-legislative tasks.

The methodology for categorising FCTC implementation status also has some limitations. By categorising implementation status as either 'yes', 'no' or 'partial' implementation, this assessment is less nuanced than the national reports within the FCTC Implementation Database. However, some of these nuances and details about FCTC implementation status are reflected within the individual country priority areas in Table 2 . Interpretation of data presented in this review should therefore be considered with these limitations in mind.

Despite these limitations, this review provides a comprehensive overview of FCTC implementation across the WHO Europe Region compiled from various data sources. It further guides country stakeholders on which tobacco control policies and measures to prioritise.

\section{CONCLUSIONS}

Global tobacco control efforts have advanced significantly in recent years, with the WHO FCTC being increasingly adopted by countries worldwide, along with the newly adopted EU TPD. Across the WHO Europe Region, considerable variability in FGTC implementation exists, resulting in a need for a detailed understanding of countrylevel implementation and tobacco control priority areas. In the current review, we covered the FCTC implementation status and recent tobacco control policy achievements in 47 countries of the WHO Europe Region, and subsequently identified areas for improvement, according to the WHO MPOWER framework. Our findings highlight the multitude of successes in tobacco control efforts across the region in recent years, yet point out the need to address gaps in FCTC implementation. By focusing efforts on these priority areas, tobacco control policy makers, researchers and other stakeholders can more strategically implement measures for effectively reducing tobacco consumption, and thereby, tobaccoinduced morbidity and mortality.

\section{Table 2. Recent achievements in tobacco control policy adoption and future priority areas for countries in the WHO Europe Region}

\begin{tabular}{|c|c|c|}
\hline Country & Recent Achievements & Priority Areas \\
\hline Albania & $\begin{array}{l}\text { On } 23 \text { August 2014, the } \\
\text { Albanian National Assembly, } \\
\text { on the proposal of the } \\
\text { Council of Ministers, adopted } \\
\text { amendments to the } 2006 \text { Act } \\
\text { on the 'Protection of Health } \\
\text { from Tobacco Use'. According } \\
\text { to the amendments, smoking } \\
\text { has been completely banned in: } \\
\text { workplaces, health institutions } \\
\text { (except for patients of mental } \\
\text { health institutions), educational } \\
\text { establishments, public transport } \\
\text { facilities including taxis, } \\
\text { indoor shopping malls, bars, } \\
\text { restaurants, discos and night } \\
\text { clubs, cultural and sports } \\
\text { facilities, shared areas of private } \\
\text { home buildings, and enclosed } \\
\text { areas of any other public } \\
\text { facilities }\end{array}$ & $\begin{array}{l}\text { (1) Monitor tobacco use for both adults and youth: Currently Albania only monitors } \\
\text { prevalence data for either adults or youth, but not for both. (2) Include pictorial warnings } \\
\text { on tobacco product health warnings: Health warnings are legally mandated to cover } \\
50 \% \text { of the front and the rear of the principal display area. Warnings do not include a } \\
\text { photograph or graphics. (3) Offer help to quit tobacco use: Albania only provides cessation } \\
\text { support in some health clinics or other primary care facilities. No toll-free quit-line } \\
\text { or nicotine replacement therapy is available. (4) Enforce bans on tobacco advertising, } \\
\text { promotion and sponsorship: Albania does not have a ban on advertising on the internet or } \\
\text { ban on tobacco-products display at point of sale. (5) Raise taxes on tobacco: In Albania, a } \\
\text { pack of cigarettes costs } 200 \text { ALL (US } \$ 1.93) \text {, of which } 64.08 \% \text { is tax (16.67\% is value added } \\
\text { and } 45.0 \% \text { is excise tax) }{ }^{25} \text {. }\end{array}$ \\
\hline
\end{tabular}


Andorra

In 2012 Andorra adopted Law No. 7/2012 of 17 May on protection from exposure to second hand smoke ${ }^{26}$.

Armenia

Armenia has adopted stricter regulations on tobacco product packaging and labelling (Decision No. 18 of 17 March 2017 the Eurasian Economic Commission), implements paragraph 27 of the Technical Regulations for Tobacco Products and regulates the format and position of picture and text warnings, as well as the images to be used, on tobacco product packaging. The required warnings and images must appear on all tobacco product packages for retail sale by 15 November $2017^{28}$.

Austria A Federal Law amending both the Tobacco Act, the Income Tax Act 1988, the Corporation Tax Act 1988, the Labour Inspect Act 1993, and the Federal Officials Protection Act (BGBI No. 101/2015) was published in the Austrian Federal Journal of Law on 13 August 2015 and will enter into force on 1 May 2018. The law includes the introduction of a comprehensive non-smoking protection in eating places, extension of the scope of the Tobacco Law to the use of water pipes and related products in areas covered by smoking bans, and introduction of a non-taxexempt premium ${ }^{30}$.
(1) Monitor tobacco use for both adults and youth: Andorra only monitors prevalence data for either adults or youth, but not for both. (2) Become a party to the WHO FCTC: Andorra has not signed the WHO FCTC yet. (3) Protect people from tobacco smoke: Indoor areas such as healthcare facilities, educational facilities, except for universities, and government facilities, are smoke-free. However, designated smoking rooms are permitted under the law in restaurants, cafes, pubs and bars, and indoor offices and workplaces. (4) Offer help to quit tobacco use: Nicotine replacement therapy as well as smoking cessation medicines are available in pharmacies without a prescription. However, these are not covered, and smoking cessation programmes are partially available. (5) Enforce bans on tobacco advertising, promotion and sponsorship: Andorra has no legislation on both direct and indirect advertising, promotion and sponsorship of tobacco products ${ }^{27}$.

(1) Protect people from tobacco smoke: No funds are dedicated to enforcement and no system is in place for citizen complaints and further investigations. (2) Offer help to quit tobacco use: No toll-free quit-line is available. (3) Warn about the dangers of tobacco: Health warnings are legally mandated to cover $30 \%$ of the front and rear of the principal display area, with five such warnings approved by law. The warnings do not include a photograph or graphic. (4) Enforce bans on tobacco advertising, promotion and sponsorship: Armenia does not ban direct advertisement in national and international radio and television, on billboards, advertising on internet, and free distribution in mail. (5) Raise taxes on tobacco: A pack of cigarettes in Armenia costs 600.00 AMD $^{1}$ (US\$ 1.48), of which $33.33 \%$ is tax $(16.67 \% \text { is value-added and } 16.67 \% \text { excise tax })^{29}$.

(1) Protect people from tobacco smoke: There is questionable enforcement. (2) Decrease tobacco industry interference: There is a law on lobbying, but it is weak and not controlled $^{31}$. (3) Raise taxes on tobacco: For cigarettes the total tax (excise + VAT) was $77,46 \%$ of the weighted-average price in 2015. The percentage of the ad valorem tax for cigarettes is $40 \%$ of the retail price. For cigars and cigarillos, an ad valorem tax of $13 \%$ of the retail-selling price applies, while for fine-cut tobacco the ad valorem tax rate is 56\%. Furthermore, value added tax (VAT) of 20\% applies to all tobacco products. The WAP in 2016 was 4,48 EUR. (4) Offer help to quit tobacco use: Austria records smoking status of patients in medical notes or patient files, offers a network cessation support and its reimbursement, and has a national quit-line. Family doctors are not reimbursed for providing brief advice and medication treatment is not reimbursed. (5) Warn about the dangers of tobacco: Public awareness work is mainly left to the NGOs. (6) Enforce bans on tobacco advertising, promotion and sponsorship9. (7) Enforce age-limit to selling tobacco products: Prohibited to sell below age 16, but no enforcement 17. 


\section{Azerbaijan}

Belarus
Belarus, as part of the Eurasian Economic Union, has adopted stricter regulations on tobacco product packaging and labelling, which will fully enter into force on 15 November 2017. The Decision implements Paragraph 27 of the Technical Regulations for Tobacco Products and regulates the format and position of picture and text warnings, as well as the images to be used, on tobacco product packaging. The required warnings and images must appear on all tobacco product packages for retail sale by 15 November 2017. The Decision applies to all members of the Eurasian Economic Union ${ }^{33}$.
(1) Protect people from tobacco smoke: Health-care and education facilities, including universities, are completely smoke-free in Azerbaijan. Dedicated funds for enforcement and a system for citizen complaints and further investigation are in place. Neither establishments nor patrons are fined for violations of current smoke-free legislation. Health-care facilities and education facilities are smoke free while government facilities, indoor offices and workplaces, restaurants, cafes, pubs and bars, and public transport is not smoke-free. (3) Offer help to quit tobacco use: Smoking cessation services are not available in Azerbaijan. Nicotine replacement therapy can legally be purchased in a pharmacy without a prescription but is not cost-covered. No toll-free quit-line is available. (4) Warn about the dangers of tobacco: Health warnings are legally mandated to cover $30 \%$ of the front and back of the principal display area, with one health warning approved by law. The warning appears on each package, and any outside packaging and labelling used in retail sale. The law mandates font size/style and colour of the health warning, which is written in the principal language(s) of the country. It does not include a photograph or graphic however, and does not describe the harmful effects of tobacco use on health. (5) Enforce bans on tobacco advertising, promotion and sponsorship: Through a law adopted in 1997 and amended several times since, Azerbaijan has bans in place on all forms of direct and some forms of indirect advertising. The law does not require fines for violations of these bans There is no ban on indirect advertising through promotional discounts, nontobacco products identified with tobacco brand names, appearance of tobacco products on television and/or in films, in sponsored events and at points of sale. (6) Raise taxes on tobacco: A pack of cigarettes in Azerbaijan costs 1.40 AZN1 (US\$ 1.79), of which $17.30 \%$ is $\operatorname{tax}(15.25 \% \text { is value-added tax, } 2.02 \% \text { excise tax, and } 0.03 \% \text { import duty })^{32}$.

(1) Protect people from tobacco smoke: No indoor public places in Belarus are completely smoke-free. Under current legislation, special places for smoking (equipped to Ministry of Health requirements) are allowed in all indoor public places. Smoking violations incur fines for the patron, but not the establishment. A system for citizen complaints and further investigations is in place, but no funds are dedicated to enforcement. (2) Offer help to quit tobacco use: Smoking cessation services are available in some health clinics and other primary care facilities, with costs fully covered by the National Health Service/Insurance. Cessation support is also provided in some hospitals and offices of health professionals, with costs being partially covered. Nicotine replacement therapy can be purchased over the counter in a pharmacy without a prescription, but is not cost-covered. No toll-free quit-line is available. (3) Warn about the dangers of tobacco: Health warnings are legally mandated to cover $30 \%$ of the front and back of the principal display area, with six such warnings approved by law. They appear on each package and any outside packaging and labelling used in retail sale, and describe the harmful effects of tobacco use on health. The position of health warnings on packages rotates and the messages are written in the principal language(s) of the country. The law does not, however, mandate font size/ style and colour for package warnings, and the warnings do not include a photograph or graphics. (4) Enforce bans on tobacco advertising, promotion and sponsorship: Through a law adopted in 2007 and amended in 2008, Belarus has bans in place on several forms of direct and indirect advertising. The law requires fines for violations of these bans ${ }^{34}$. 
Belgium

Bosnia \&

Herzegovina
(1) Ensure implementation of WHO FCTC Article 5.3: No legislative, executive, administrative or other measures or, where appropriate, programmes with the purpose of protecting public health policies with respect to tobacco control from commercial and adopted a Decree to regulate the production and sale of electronic cigarettes in Belgium. The provisions concerning production of electronic cigarettes containing nicotine entered into force on 17 January $2017^{35}$. On 5 February 2016, Belgium adopted a Decree concerning the manufacture and sale of tobacco products, which obliges manufacturers of tobacco products in Belgium to annually provide information to the Belgian authorities concerning the tobacco products. This includes a list of all product ingredients, tar emission level, $\mathrm{CO}$ and nicotine, volume and sale etc. The decree transposes some measures of the TPD ${ }^{36}$.

. other vested interests of the tobacco industry are reported by Belgium. (2) Spending on public information campaigning: Belgium has a very low record of spending on public information campaigns. (3) Large direct health warnings: Belgium has introduced health warning labels covering $65 \%$ of the packet and pictorial health warnings on both cigarette packs and roll-your-own tobacco. Belgium has not adopted plain packaging. (4) Treatment to help smokers stop: Belgium takes measures to record smoking status in medical notes, has a national quit-line, offers some network cessation support and partial reimbursement of medicines. Belgium doctors are not reimbursed for providing brief advice'.

(1) Monitor tobacco use for both adults and youth: Bosnia \& Herzegovina only monitors prevalence data for either adults or youth, but not for both. (2) Protect people from tobacco smoke: No indoor public places in Bosnia and Herzegovina are completely smoke-free. Designated smoking rooms with strict technical requirements are allowed in all indoor public places under the current legislation of both the Federation of Bosnia and Herzegovina and the Republika Srpska. Smoking violations consist of fines on the establishment and the patron. (3) Offer help to quit tobacco use: Smoking cessation services are available in some health clinics or other primary care facilities in both the Federation of Bosnia and Herzegovina and the Republika Srpska, and health services or health insurances fully cover the costs. All family medicine doctors have been trained in cessation treatment both in the Federation of Bosnia and Herzegovina and in the Republika Srpska. Nicotine replacement therapy can be purchased over the counter in a pharmacy but is not cost-covered, and no toll-free quit-line is available. (4) Enforce bans on tobacco advertising, promotion and sponsorship: The Federation of Bosnia and Herzegovina has a ban, through a law adopted in 1998 and last amended in 2012, on several forms of direct and indirect advertising. The law requires fines for violations of these direct and indirect advertising bans. There are no bans on direct advertising at point of sale or on the internet, nor on indirect advertising through bans on free distribution in mail or other means, promotional discounts, non-tobacco products identified with tobacco brand names, appearance of tobacco products on television and/or in films, tobacco products display at point of sale. (5) Warn about the dangers of tobacco: In both the Federation of Bosnia and Herzegovina and the Republika Srpska, health warnings are legally mandated to cover 35\% of the front of the principal display area. They appear on each package and any outside packaging and labelling used in the retail sale, and describe the harmful effects of tobacco use on health. Moreover, health warnings rotate on packages and are written in the principal language(s) of the country. The law also mandates font style, font size and colour for package warnings. However, the warnings do not include a photograph or graphics. (6) Raise taxes on tobacco: In Bosnia and Herzegovina, a pack of cigarettes costs 3.70 BAM3 (US\$ 2.53), of which $82.33 \%$ is $\operatorname{tax}(14.53 \%$ is value added and $66.32 \%$ is excise tax, with $1.5 \%$ for import tax $)^{37}$. 
Bulgaria

Croatia

Cyprus
On 24 March 2016, Bulgaria adopted Decree No. 89 to Promulgate the Law on Amending and Supplementing the Law on Tobacco and Tobacco Products, which transposes the provisions of the EU TPD ${ }^{38}$.

On 18 May 2017, Croatia adopted the Law on Restricting the Use of Tobacco and Related Products, which transposes the TPD into national law ${ }^{40}$.
(1) Protect people from tobacco smoke: Almost all enclosed public places in Bulgaria are completely smoke-free. Smoking violations consist of fines on the patron but not on the establishment. Funds are dedicated for enforcement, and a system is in place for citizen complaints and further investigations. (2) Offer help to quit tobacco use: Smoking cessation services are available, of which, some are cost-covered, but Bulgaria only provides cessation support in some health clinics or other primary care facilities. Nicotine replacement therapy can be purchased over the counter in a pharmacy but is not cost covered, and a toll-free quit-line is available. (3) Warn about the dangers of tobacco: Health warnings are legally mandated to cover $30 \%$ of the front and $40 \%$ of the back of the principal display area, whereby 16 health warnings are approved by law. However, the warnings do not include a photograph or graphics. Health warnings will have to cover 65 $\%$ of the front and the back of cigarette and roll-your-own tobacco (RYO) packs, following TPD implementation. Total tobacco control expenditures, which may include mass media campaign expenditures, amount to US\$25033 in Bulgaria, which is less than US\$ 0.05 per capita and classified as a low level of funding. (4) Enforce bans on tobacco advertising, promotion and sponsorship: Bulgaria does not ban advertising in international magazines and newspapers, billboards, at points of sale, in free distribution in mail, promotional discounts, non-tobacco products identified with tobacco brand names, appearance of tobacco products in television and films and sponsored events. (5) Raise taxes on tobacco: In Bulgaria, a pack of cigarettes costs 4.70 BGN 1 (US\$ 3.21), of which $82.65 \%$ is tax $(16.67 \%$ is value added and $65.98 \%$ is excise tax ${ }^{39}$.

(1) Protect people from tobacco smoke: Croatia has not installed a complete smoke-free policy in government facilities, indoor offices and workplaces, restaurants, cafes, pubs and bars, public transport, and all other indoor public places. (2) Warn about the dangers of tobacco: Health warnings are legally mandated to cover $65 \%$ of the front and the back of cigarette and roll-your-own tobacco (RYO) packs following TPD implementation. (3) Offer help to quit tobacco use: Smoking cessation services are available of which some are cost-covered, but Croatia only provides cessation support in some health clinics or other primary care facilities. Nicotine replacement therapy can be purchased over the counter in a pharmacy but is not cost-covered, and no toll-free quit-line is available. (4) Enforce bans on tobacco advertising, promotion and sponsorship: Croatia does not have bans on tobacco companies publicizing their activities, funding or making contribution to smoking prevention media campaigns. (5) Raise taxes on tobacco: In Croatia, a pack of cigarettes costs 23.00 HRK (US\$ 4.04), of which $75.26 \%$ is tax (20.00\% is value added and $55.26 \%$ is excise $\operatorname{tax})^{43}$.

(1) Raise taxes on tobacco: $29 \%$ of the proportion of the retail price of the most popular price category of tobacco product consists of taxes in Cyprus. Excise tax is levied through a combination of specific and ad valorem taxes. (2) Enforce ban on underage sales: No progress has been made on this issue for the past two years $(2014,2015)$. In the new proposed legislation, it will be illegal to sell packs of cigarettes with less than 20 items and regarding roll-your-own tobacco no less than $30 \mathrm{~g}$. This will ensure that no low-cost tobacco is available for purchasing by children. (3) Enforce bans on tobacco advertising, promotion and sponsorship: Cyprus has a comprehensive ban on all tobacco advertising, promotion and sponsorship. However, the ban does not cover display and visibility of tobacco products at points of sale, the internet, brand stretching and or sharing, product placement, or the depiction of tobacco use in entertainment media products ${ }^{9}$. 


\section{Czech} Republic

On 9 December 2016, the Czech Republic adopted the Act on the protection of health from harmful effects of addictive substances, which introduces a smoking ban on restaurants, bars, theatres, cafes and cinemas. Movie theatres, concert venues, exhibition halls, and indoor sports settings are banned from having separate rooms for smokers. The law came into force on 31 May $2017^{43}$. The Decree 37/2017 on Electronic Cigarettes, Refill Containers, and Herbal Products for Smoking entered into force on 1 March 2017, transposing the final provisions on e-cigarettes laid out in the TPD. The decree regulates safety and quality requirements, rules on labelling of e-cigarettes, including prohibited elements and features, reporting obligation of manufacturers and importers of e-cigarettes, and requirements in relation to cross-border distance sale of e-cigarettes ${ }^{44}$. The Decree No. 261/2016 on Tobacco Products was adopted on 28 July 2016 and entered into force on 7 September 2016. It regulates labelling, emission levels of cigarettes, security labels and illegal traits of cigarettes ${ }^{45}$.

Denmark The law on tobacco products (Law no. 608 of 07/06/2016) was adopted on 2 June 2016 and regulates the production, presentation and sale of tobacco products ${ }^{47}$. The law on electronic cigarettes (Law no. 426 of 18/05/2016) was adopted on 10 May 2016 and enforced on 20 May 2016. It prohibits the use of e-cigarettes in certain types of work places, especially institutions, schools, youth places, in public transportation and taxis $^{48}$.
(1) Protect people from tobacco smoke: Czech Republic has adopted a comprehensive smoke-free regulation that will enter into force on 31 May 2017. The ban does not enforce the maintenance of separate smoking areas in restaurants. E-cigarettes and hookahs are allowed in cafes, bars, restaurants, hospitals, schools and shopping centres. Smoking is still allowed in uncovered public transportation. (2) Enforce bans on tobacco advertising, promotion and sponsorship: Czech Republic has a ban on tobacco advertising in television and radio, outdoor advertising (i.e. posters), cinema advertising, and advertising in print media (i.e. newspapers). There is, however, no ban of point of sales advertising or display of tobacco products at points of sale. (3) Warn about the dangers of tobacco: Health warnings are legally mandated to cover $65 \%$ of the packet and include pictorial health warnings. Czech Republic has not implemented plain packaging ${ }^{9}$. (4) Prevent illicit trade of tobacco products: The WHO Protocol to Eliminate Illicit Trade in Tobacco Products provides tools for preventing illicit trade. Czech Republic has not yet signed the protocol ${ }^{46}$.
(1) Raise taxes on tobacco: In Denmark, the retail price of a pack of cigarettes at weightedaverage price was 5,57 EUR ( 1 July 2016) of which $75.00 \%$ is tax levied in combination of specific and ad valorem taxes ${ }^{9}$. (2) Enforce bans on tobacco advertising, promotion and sponsorship: There is a general ban on tobacco promotion and sponsorship. But there is no display ban in retail outlets and the industry has found loopholes in the ban, e.g. the summer music festivals (which often target youth) are heavily sponsored by tobacco companies. They can use the festival to promote and brand new and special tobacco products and 'festival editions'. (3) Protect people from tobacco smoke: There is a smoking ban, but with exemptions, as smoking is allowed in designated smoking rooms or smoking cabins at workplaces. Smoking is also allowed in restaurants and bars below $40 \mathrm{~m} 2$. In private day-care centres, small children are not protected against second-hand smoke, as smoking in the private home of the care giver is allowed (except in rooms where the children are mostly cared for) and outside workhours. Smoking is further allowed at e.g. nursing homes and other institutional facilities, which are also private homes for the residents ${ }^{49}$. 
Estonia

The Act to Amend the Tobacco Act was adopted on 18 January 2016 and entered into force on 20 May 2016, and 1 June 2017 according to specific provisions. It regulates the content, production, presentation and sale of tobacco products ${ }^{50}$. The amendments to the Tobacco Act were adopted on 8 July 2016. The act transposes the provisions of the TPD ${ }^{51}$.

Finland

Finland adopted and implemented a new tobacco control law, enforced as of 15 August 2016, which transposes the TPD into national law ${ }^{54}$.

France The Public Health Code was adopted on 3 April 2017 and complimented by multiple Administrative Acts, Decrees and Orders. The Code implements the TPD in France. Plain packaging of on the French market as of 1 January 2017. Furthermore, the National Assembly has adopted the new social security budget, which increases tobacco taxes ${ }^{55}$.

Georgia The new Georgian tobacco control law was adopted in May 2017 and comes into force in 2018. The law includes smokefree policies in public places and work places, and ban on Tobacco Advertising, Promotion and Sponsorship ${ }^{58,59}$.
(1) Prevent illicit trade of tobacco products: The WHO Protocol to Eliminate Illicit Trade in Tobacco Products provides tools for preventing illicit trade. Estonia has not yet signed the protocol. In Estonia there is no tobacco industry since 1999. All tobacco products are imported either in legal or illicit ways. However, foreign tobacco companies are trying to maintain and further their commercial interests through trading with the chains of numerous supermarkets, lobbying in the parliament and at municipal level, and using the media to promote tobacco products ${ }^{52}$. (2) Raise taxes on tobacco: In Estonia, the retail price cigarettes weighted-average price is 3,07 EUR (1 July 2016) of which taxes are levied in combination of specific and ad valorem taxes. The rate of taxation for smoking tobacco products at all levels of Government is $34 \%$ of the retail price. The rates of taxation for tobacco products were raised 6\% in the year 2014, not raised in 2015 and $8 \%$ was planned in $2016^{53}$. (3) Enforce bans on tobacco advertising, promotion and sponsorship: Estonia has a ban on tobacco advertising on radio and television, outdoor advertising, print media and point of sale advertising. There is no ban on display of tobacco products at the point of sale. (4) Offer help to quit tobacco use: Estonia offers a national quit-line in all major regions of the country with counsellors answering at least 30 hours a week. Estonia offers no reimbursement of medications, no recording of smoking status in medical notes, and no reimbursement to family doctors for providing brief advice ${ }^{46}$.

(1) Raise taxes on tobacco: In Finland, the retail price of cigarettes (weighted-average price) is 5,68 EUR ( 1 July 2016) ${ }^{9}$ of which $83,2 \%$ taxes are levied in combination of specific and ad valorem taxes. (2) Warn about the dangers of tobacco use: Finland has health warnings corresponding to TPD regulation, with pictorial health warnings on cigarette packs and rolling tobacco. Finland does not have plain packaging of tobacco products. (3) Offer help to quit tobacco use: Finland offers a national quit-line in all major regions of the country, cessation support network with some limitations, and partial reimbursement of medications. Finland has no recording of smoking status in medical notes and offers no reimbursement to family doctors for providing brief advice.

(1) Raise taxes on tobacco: In France, the retail price of cigarettes (weighted-average price) is 5,68 EUR ( 1 July 2016) ${ }^{9}$ of which $83,2 \%$ taxes are levied in combination of specific and ad valorem taxes. Prices on tobacco products will gradually increase following the adoption of the new social security budget ${ }^{56}$. The objective of the government is to reach 10 euros for the price of a cigarette pack in 2020. (2) Warn about the dangers of tobacco use - increase public info campaigns: In 2015 France authorities spent 0.14 EUR PPS (Purchasing Power Standard) per capita on Tobacco Control. (3) Offer help to quit tobacco use: France offers a national quit-line in all major regions of the country with counsellors' presence at least 30 hours a week, cessation support network with some limitations and partial reimbursement of medications. France has no recording of smoking status in medical notes and offers no reimbursement to family doctors for providing brief advice ${ }^{57}$.

(1) Raise taxes on tobacco: A pack of cigarettes in Georgia costs 2.20 GEL1 (US\$ 1.26), of which $49.35 \%$ is tax (15.25\% is value-added and $34.09 \%$ excise tax). (2) Warn about the dangers of tobacco use: Health warnings are legally mandated to cover $30 \%$ of the front and back of the principal display area, with 12 such warnings approved by law. They appear on each package and any outside packaging and labelling used in retail sale, and describe the harmful effects of tobacco use on health. The law also mandates font size/style and colour for package warnings. The position of health warnings on packages rotates and the messages are written in the principal language(s) of the country. Pictorial warnings on packages are optional, not mandatory. (3) Offer help to quit tobacco use: Smoking cessation services are available in some health clinics and other primary care facilities, with costs partially covered by the National Health Service/Insurance. Nicotine replacement therapy is not available, but varenicline is sold legally in Georgia and can be purchased in a pharmacy without a prescription; the cost of this product is not covered. A tollfree quit-line is available. (4) Enforce bans on tobacco advertising, promotion and sponsorship: Through laws on advertising (adopted in 1998 and amended in 2008) and tobacco control (adopted in 2010), Georgia has bans in place on some forms of direct and indirect advertising. The law does not require fines for violations of these bans. (5) Protect people from tobacco smoke: Health-care and education facilities, including universities, are completely smoke-free in Georgia. Smoking violations incur fines for the establishment and patron, but no funds are dedicated to enforcement and no system is in place for citizen complaints and further investigations. There is no smoking ban on government facilities, workplaces, restaurants, cafes, pubs and bars, public transport and all other indoor public places ${ }^{60}$. 
Germany The German Tobacco Products Law, adopted on 4 April 2016, and its supporting ordinance transpose the provisions of the TPD to national law. For products made before 20 May 2016, or put into free circulation for the first time, a transitional period is applied with deadline of 20 May $2017^{6}$

Greece

On 20 September 2016, Greece adopted Law no. 4419/2016 in view of implementing the TPD related with the manufacture, presentation, and the sale of tobacco products and similar products $^{62}$.

Hungary The Decree 239/2016 (of 16 August 2016) of the Hungarian Government transposes the TPD into national law by introducing new rules on tobacco packaging and amending the earlier regulation on the application of health protection fine (Decree 39/2013 of 14 February 2013). This includes the requirement for cigarette packages to carry pictorial health warnings of $65 \%$ of the front and back of packages. The last day for selling other packs with smaller health warnings was 20 May 2017. After 20 May 2019, all retailers need to conform with the regulation of standardised packaging ${ }^{64}$.

Iceland
(1) Enforce bans on tobacco advertising, promotion and sponsorship: Germany has a ban on advertising of tobacco products on television and radio, in printed material such as newspapers, and a ban on international sponsorship. Germany does not have a ban on tobacco advertising in cinemas and out-door areas, and thus remains the only EU country that still allows tobacco advertising on billboards. There is also no ban on point of sales or display ban, national sponsorship or indirect advertising. (2) Protect people from tobacco smoke: Germany does not have a complete ban of smoking in bars and restaurants. Legislation of smoking in bars and restaurants is a responsibility of the regions (Länder). Most Länder ban smoking in bars and restaurants, but may allow smoking rooms or some exceptions. Smoking is banned in public transport and more than $50 \%$ work places are smoke-free. (3) Warn about the dangers of tobacco use: Health warnings will have to cover $65 \%$ of the front and the back of cigarette and roll-your-own tobacco (RYO) packs following TPD implementation. Germany has not implemented plain packaging. (4) Raise taxes on tobacco: The retail price for a pack of cigarettes in weighted-average price in Germany was 5,34€ as of 1 July 2016. Of the retail price of the most popular price category of tobacco product $77 \%$ consists of taxes ${ }^{9}$.

(1) Enforce bans on tobacco advertising, promotion and sponsorship Greece has a ban on advertising of tobacco products on television and radio, in out-door advertisement, printed material such as newspapers, and a ban on international sponsorship. Greece does not have a ban on tobacco advertising in cinemas, on point of sales or display ban, national sponsorship or indirect advertising. (2) Protect people from tobacco smoke: Greece has a smoke-free law, which is enforced only to a limited extent. There are legislative restrictions to smoking in bars and restaurants, but less than $50 \%$ of the bars and restaurants are smoke-free. Greece has legislative restrictions on smoking in workplaces, but less than $50 \%$ of workplaces are smoke-free. Smoking is banned in public transport. (3) Warn about the dangers of tobacco use: Greece has enforced pictorial health warnings on tobacco products covering $65 \%$ of the front and the back of cigarette and roll-your-own tobacco, following provisions of the Tobacco Products Directive. Greece has not implemented plain packaging. (4) Raise taxes on tobacco: The retail price for a pack of cigarettes in weighted-average price in Greece was $3,71 €$ as of 1 July $2016^{9}$. Of the retail price of the most popular price category of tobacco product $68 \%$ consists of taxes levied in a combination of specific and ad valorem taxes ${ }^{63}$. (1) Protect people from tobacco smoke: Hungary has a ban on smoking in bars, restaurants and public transport. Hungary has a complete ban on smoking in work places but with closed ventilated designated smoking rooms enforced ${ }^{9}$. (2) Raise taxes on tobacco: In Hungary, the retail price cigarettes weighted-average price is 3,38 EUR (1 July 2016) of which $75.9 \%$ is tax levied in combination of specific, ad valorem taxes with minimum excise duty and VAT on cigarettes. (3) Enforce bans on tobacco advertising, promotion and sponsorship: Hungary has a ban on tobacco advertising on tv and radio, in cinemas and out-door advertising, in printed material such as newspapers. There is no ban on point-ofsale advertising or display of tobacco products at point of sale $e^{65}$.

(1) Offer help to quit tobacco use: Iceland does not have a legal or financial incentive to record smoking status in all medical notes or patient files, family doctors are not reimbursed for providing brief advice. Iceland has a national quit-line, with counsellors answering less than 30 hours a week. Tobacco dependence treatment medication is not reimbursed. (2) Warn about the dangers of tobacco: Pictorial health warnings are found on cigarette packs and RYO tobacco. Iceland does not have plain packaging of tobacco products and health warnings on packages cover $50 \%$ or less than the package. A data set of the new pictorial warnings have been laid out with text warnings in Icelandic language and are in the preparation stage. (3) Raise taxes on tobacco: The price for a package of Marlboro cigarettes minus $10 \%$ was 8,35 EUR per 1 July $2016^{9}$. Of the retail price of the most popular price category of tobacco product consists of $56 \%$ taxes levied as specific taxes ${ }^{66}$. 
Ireland The Public Health (Standardised (1) Raise taxes on tobacco: The retail price of a package of cigarettes weighted-average Packaging of Tobacco) Act price per 1 July 2017 is 9,69 EUR in Ireland. The price is 6,68 EUR to Purchasing Power

2015 was passed in March 2015 Standard per capita ${ }^{9}$. Of the retail price of the most popular price category of tobacco and, once implemented, will require that corporate labels and branding be removed from product packaging and replaced with brand names in a standard colour and font. Regulations are pending commencement of the Act ${ }^{67}$. The Public Health (Standardised Packaging of Tobacco) Act 2015 (Commencement) Order 2017 establishes the date by which the remaining provisions of the Public Health (Standardised Packaging of Tobacco) Act 2015 are to enter into force. Remaining stock may continue to be sold at retail for one year, at which point plain packaging will be required for all tobacco products. The European Union (Manufacture, Presentation and Sale of Tobacco and Related Products) Regulations 2016 (S.I. No. 271 of 2016) implement the TPD and revise the health warnings required on tobacco product packaging, regulate cross-border distance sales, and regulate e-cigarettes and herbal smoking products ${ }^{68}$.

Israel product in Ireland consists of $79.7 \%$ taxes levied in combination of specific and ad valorem $\operatorname{taxes}^{69}$. (2) Offer help to quit tobacco use: Ireland has a national quit-line in all major regions of the country with quit-line counsellors answering at least 30 hours a week. $A$ network of smoking cessation support and its reimbursement cover the whole country and medications are totally reimbursed or free to users. However, Ireland has no legal or financial incentive to record smoking status in all medical notes or patient files, and family doctors are not reimbursed for providing brief advice.

(1) Protect people from tobacco smoke: Health care facilities and education facilities, except universities, are completely smoke free in Israel. In universities, government facilities and restaurants, designated smoking rooms with strict technical requirements are allowed under the current legislation. Rather than complete smoke-free workplaces, smoking is permitted in private offices. In addition, cafés, pubs and bars are allowed to set aside a quarter of their space for smokers, as long as it is in a separate room. Smoking violations consist of fines on the establishment and the patron. A system is in place for citizen complaints and further investigations; however, no funds are dedicated for enforcement. (2) Offer help to quit tobacco use: Smoking cessation services are available in some health clinics or other primary care facilities, and the National Health Service/ Insurance fully covers its costs. A toll-free quit-line is available and nicotine replacement therapy (NRT) can be purchased over the counter in a pharmacy. NRT is partially covered by the national health service or the national health insurance. (3) Warn about the dangers of tobacco: Health warnings are legally mandated to cover $30 \%$ of the front and the back of the principal display area, whereby 13 health warnings are approved by law. They appear on each package and any outside packaging and labelling used in the retail sale, and describe the harmful effects of tobacco use on health. Moreover, health warnings rotate on packages and are written in the principal language(s) of the country. The law also mandates font style, font size and colour for package warnings. However, the warnings do not include a photograph or graphics. (4) Enforce bans on tobacco advertising, promotion and sponsorship: Israel has a ban, through a law adopted in 1983 and last amended in 2008, on few forms of direct and indirect advertising. The law requires fines for violations of these direct and indirect advertising bans. Bans on advertising are not implemented in local magazines and newspapers, billboards and outdoor advertising, and promotional discounts among others. (5) Raise taxes on tobacco: In Israel, a pack of cigarettes costs 30.00 ILS (US\$ $8.75)$, of which $84.28 \%$ is tax $(15.25 \% \text { is value added and } 69.03 \% \text { is excise tax })^{70}$. 
Italy On 12 January 2016, Italy adopted the Legislative Decree No. 6: Implementation of Directive 2014/40/EU on streamlining the legislative, regulatory and administrative provisions of the member states regarding the processing, presentation and sale of tobacco products and related products $^{71}$. The Decree transposes the TPD into national law.

Kazakhstan As part of the Eurasian Economic Union, Kazakhstan has adopted stricter regulations on tobacco product packaging and labelling, which will fully enter into force on 15 November 2017. The decision implements Paragraph 27 of the Technical Regulations for Tobacco Products and regulates the format and position of picture and text warnings, as well as the images to be used, on tobacco product packaging. The required warnings and images must appear on all tobacco product packages for retail sale by 15 November 2017. The Decision applies to all members of the Eurasian Economic Union ${ }^{19}$.

Kyrgyzstan As part of the Eurasian Economic Union, Kyrgyzstan has adopted stricter regulations on tobacco product packaging and labelling, which will fully enter into force on 15 November 2017. The decision implements Paragraph 27 of the Technical Regulations for Tobacco Products and regulates the format and position of picture and text warnings, as well as the images to be used, on tobacco product packaging. The required warnings and images must appear on all tobacco product packages for retail sale by 15 November 2017. The Decision applies to all members of the Eurasian Economic Union ${ }^{19}$.
(1) Protect people from tobacco smoke: Italy has a complete ban in bars and restaurants, but with closed, ventilated, designated smoking rooms; a full ban in public transport, public places and private cars. In the work place there are meaningful restrictions enforced and more than $50 \%$ of the workplaces are smoke-free. (2) Offer help to quit tobacco use: Italy has a national quit-line or quit-lines in major regions of the country with counsellors answering at least 30 hours a week. (3) Warn about the dangers of tobacco: Health warnings are legally mandated to cover $65 \%$ of the front and the back of cigarette and rollyour-own tobacco (RYO) packs following TPD implementation. Italy has not adopted plain packaging for tobacco products. (4) Enforce bans on tobacco advertising, promotion and sponsorship: Italy has a ban on tobacco advertising on tv and radio, in cinema, outdoors areas, in printed material and at point of sales. Italy has no ban of display of tobacco products at point of sale. There is a ban on international sponsorship, but not on national sponsorship, on internet advertising or in indirect advertising. (5) Raise taxes on tobacco: The retail price for cigarettes at weighted-average price is 4,66 EUR in Italy per 1 July $2016^{9}$. Of the retail price of the most popular price category of tobacco product consists $77 \%$ of taxes levied in combination of specific and ad valorem taxes ${ }^{72}$.

(1) Protect people from tobacco smoke: Health-care, government and education facilities, including universities, indoor offices and workplaces, and cafes, pubs and bars are completely smoke-free in Kazakhstan. Smoking violations incur fines for the establishment and patron, but no funds are dedicated to enforcement, and no system is in place for citizen complaints and further investigations. (2) Offer help to quit tobacco use: Smoking cessation services are available in some health clinics and primary care facilities and in offices of health professionals, with costs fully covered by the National Health Service/Insurance. Cessation support can also be accessed at hospitals, where the cost is partially covered, and in the community (without cost coverage). Nicotine replacement therapy can be purchased over the counter in a pharmacy without a prescription, but is not cost-covered. A toll-free quit-line is available. (3) Warn about the dangers of tobacco: Health warnings are legally mandated to cover $40 \%$ of the front and back of the principal display area, with 12 such warnings approved by law. The position of health warnings on packages rotates and the messages are written in the principal language(s) of the country. The law sets the font size/style and colour for package warnings and mandates that the warnings include a photograph or graphic. It also mandates that warnings appear on each package and any outside packaging and labelling used in retail sale. (4) Enforce bans on tobacco advertising, promotion and sponsorship: Through a law adopted in 2003 and amended in 2007 (5), Kazakhstan has bans in place on all forms of direct and some forms of indirect advertising. The law requires fines for violations of these bans. (5) Raise taxes on tobacco: $\mathrm{A}$ pack of cigarettes in Kazakhstan costs 210 KZT (US\$ 1.15), of which $39.29 \%$ is $\operatorname{tax}(10.71 \%$ is value-added tax and $28.57 \%$ excise tax $)^{73}$.

(1) Protect people from tobacco smoke: Health-care, government and education facilities, including universities, are completely smoke-free in Kyrgyzstan. Smoking violations incur fines for the patron but not the establishment. Funds are dedicated for enforcement, but no system is in place for citizen complaints and further investigations. Kyrgyzstan has no ban on smoking in indoor offices and workplaces, restaurants, cafés, pubs and bars, and public transport. (2) Offer help to quit tobacco use: Smoking-cessation services are available in most health clinics and other primary care facilities; offices of health professionals and in the community; the National Health Service/Insurance partially covers costs, except for cessation support in the community. Nicotine replacement therapy is not available, but varenicline can be purchased legally without a prescription in a pharmacy; the cost of this product is not covered. A tollfree quit line is available. (3) Warn about the dangers of tobacco: Health warnings are legally mandated to cover $40 \%$ of the front and back of the principal display area, with 12 such warnings approved by law. They appear on each package and any outside packaging and labelling used in retail sale, describing the harmful effects of tobacco use on health. The law also mandates font size/style and colour for package warnings. The position of health warnings on packages rotates; messages are written in the principal language(s) of the country and include a photograph or graphic. (4) Enforce bans on tobacco advertising, promotion and sponsorship: Through laws on advertising (adopted in 1998) and tobacco control (adopted in 2006), both amended several times since, Kyrgyzstan has bans in place on most forms of direct and indirect advertising. The law requires fines for violations of these bans. There is no ban on tobacco advertising at point of sale and no display ban of tobacco products at point of sale. (5) Raise taxes on tobacco: A pack of cigarettes in Kyrgyzstan costs 35 KGS1 (US\$ 0.68), of which $38.54 \%$ is tax ( $10.71 \%$ is value-added tax, $24 \%$ excise tax, and $3.83 \%$ import duty $)^{74}$.

Continued 
Latvia

In 2016, Latvia adopted the Cabinet Regulation No. 440 on Procedure for the Submission and Processing of Information on Tobacco Products, Herbal Products for Smoking, Electronic Cigarettes and Associated Refill Container ${ }^{75}$, the Cabinet Regulation No. 306 on the Requirements for Health Warnings to Be Placed on Packaging ${ }^{76}$, and the Law on Trade in Tobacco Products, Herbal Smoking Products, Electronic Smoking Devices and Associated Liquids ${ }^{77}$. The regulations transpose the TPD into national law.

Lithuania On 28 September 2016, Lithuania adopted the Resolution No. 958 Regarding the Amendment of Resolution No. 200 of February 23, 2004 'On Authorizing the Implementation of the Law on the Control of Tobacco, Tobacco Products and Associated Products ${ }^{78}$. On 22 July 2016, the country adopted Order No. 4-486 Regarding the Amendment of Order No. 4-609 of 29 September 2015 'On the Approval of the Contents and the Submission Procedure of the Information Associated with the Quitting of Smoking, and the Sets of Visual Warnings Displayed on the Unit Packet and on Any Associated Outer Packaging of Tobacco Products ${ }^{79}$.

Luxembourg On 26 May 2016, Luxembourg adopted the Regulation of 26 May 2016, restricts the advertising of tobacco products bans smoking in certain places and prohibits the marketing of oral tobacco products. Luxembourg also adopted the law of 13 June 2017 and regulation of the Grand Duchy of 20 June 2017, transposing the EU TPD ${ }^{81}$.
(1) Protect people from tobacco smoke: Latvia has a complete ban on smoking in bars and restaurants, but with closed, ventilated, designated smoking rooms and a full ban in public transport and public places. In the work place only meaningful restrictions are enforced and more than $50 \%$ of the workplaces are smoke-free. There is no ban on smoking in private cars. (2) Offer help to quit tobacco use: Latvia has a national quit-line with counsellors available less than 30 hours per week, and only partial reimbursement of medications. There is no legal or financial incentive to record smoking status in all medical notes or patient files, and family doctors are not reimbursed for providing brief advice. (3) Warn about the dangers of tobacco: Latvia has pictorial health warnings on cigarettes and RYO products, in accordance with TPD provisions. Latvia does not have plain packaging. (4) Enforce bans on tobacco advertising, promotion and sponsorship: Latvia has a ban on tobacco advertising on TV, radio, in cinema, outdoor areas, printed material and a ban on national and international sponsorship. There is no ban on advertising at point of sales, no display ban and no ban on indirect advertising. (5) Raise taxes on tobacco: The retail price for cigarettes at weighted-average price was 2,89 EUR per 1 July $2016^{9}$.

(1) Protect people from tobacco smoke: Lithuania has a complete ban, but with closed, ventilated, designated smoking rooms enforced. There are meaningful restrictions in the workplace, where more than $50 \%$ of workplaces are smoke-free. There is a ban on smoking in some means of public transport. (2) Offer help to quit tobacco use: Lithuania has a network of smoking cessation support and its reimbursement across the whole country is free. There is no national quit-line, no reimbursement of medications, no legal or financial incentive to record smoking status in all medical notes or patient files, and no reimbursement for family doctors providing brief advice. (3) Warn about the dangers of tobacco: Lithuania has pictorial health warnings on cigarettes and RYO products, in accordance with TPD provisions. Lithuania does not have plain packaging. (4) Enforce bans on tobacco advertising, promotion and sponsorship: Lithuania has a ban on tobacco advertising on tv and radio, in cinema, outdoor areas, printed material, international sponsorship. There is no ban on advertising at point of sales, display ban of tobacco products at point of sale or ban on national sponsorship. (5) Raise taxes on tobacco: The retail price for cigarettes at weighted-average price was 2,77 EUR per 1 July $2016^{9}$. Of the retail price of the most popular price category of tobacco product consists of $83 \%$ taxes levied in a combination of specific and ad valorem taxes ${ }^{80}$.

(1) Protect people from tobacco smoke: Luxembourg has a complete ban on smoking in cafes and restaurants, but with closed, ventilated, designated smoking rooms, full ban on smoking in public transport, a complete ban on smoking in work places, but with closed, ventilated, designated smoking rooms with at least $75 \%$ of the workplaces smoke-free. There is no ban on smoking in private cars. (2) Offer help to quit tobacco use: Luxembourg has a national quit-line with counsellors answering at least 30 hours a week, there is a legal or financial incentive to record smoking status in all medical notes or patient files and partial reimbursement of medications. There is no reimbursement of family doctors for providing brief advice. (3) Warn about the dangers of tobacco: Luxembourg has pictorial health warnings on cigarettes and RYO tobacco products covering $51-79 \%$ of the package. Health warnings will have to cover $65 \%$ of the front and the back of cigarette and rollyour-own tobacco (RYO) packs following TPD implementation. Plain packaging is not adopted. (4) Enforce bans on tobacco advertising, promotion and sponsorship: Luxembourg has a ban on tobacco advertisement on tv and radio, in cinema, outdoor areas, printed materials and national and international sponsorship. There is no ban on advertising of tobacco products at point of sale or display of tobacco products at point of sale. (5) Raise taxes on tobacco: The retail price for cigarettes at weighted-average price was 4,50 EUR or 1,66 EUR to Purchasing Power Standard per capita, as per 1 July $2016^{9}$. 
Malta

On 1 January 2017 Malta adopted the law on Smoking in Private Vehicles Regulations 2016 (L.N. 386) ${ }^{82}$. On 4 March 2016, the country adopted the law on Manufacture, Presentation and Sale of Tobacco and Related Tobacco Products Regulations, 2016 (L.N. 67) ${ }^{83}$. The laws transpose the TPD.

Monaco Monaco has adopted Law No. 1346 of 9 May 2008 on the protection against smoking ${ }^{85}$ and Ministerial Order No. 2008295 of 16 June 2008 on the application of Law No. 1346 of 9 May 2008 on the protection against smoking ${ }^{86}$.

Montenegro In 2011 Montenegro adopted the Law on Amendments to the Law on Restriction of the Usage of Tobacco Products.
(1) Protect people from tobacco smoke: Malta has meaningful restrictions to smoking in cafes and restaurants, with $50 \%$ of bars and restaurants being smoke-free. No complete ban applies to smoking in workplaces, but meaningful restrictions are enforced, and more than $50 \%$ of work places are smoke-free. There is a ban on smoking in public transport and private cars. (2) Offer help to quit tobacco use: Malta has a national quit-line, without counsellors available 30 hours per week. There is no reimbursement of medications, no legal or financial incentive to record smoking status in all medical notes or patient files, and no reimbursement of family doctors for providing brief advice. (3) Warn about the dangers of tobacco: Malta has pictorial health warnings on cigarettes and RYO tobacco products covering $51-79 \%$ of the package. Plain packaging is not adopted. (4) Raise taxes on tobacco: The retail price for cigarettes at weighted-average price was 4,92 EUR or 5,53 EUR to Purchasing Power Standard per capita, as per 1 July 2016 ${ }^{\circ}$. Of the retail price of the most popular price category of tobacco product consists of $76 \%$ taxes levied in a combination of specific and ad valorem taxes $^{84}$.

(1) Monitor tobacco use for both adults and youth: Monaco only monitors prevalence data for either adults or youth, but not for both. (2) Sign and ratify the WHO Framework Convention on Tobacco Control and the WHO Protocol to tackle illicit trade. (3) Educate and communicate on the dangers of tobacco: All tobacco products sold in Monaco are imported from France, and therefore follow French law on health warnings. France has large warnings with all appropriate characteristics since 2016. (4) Adopt bans on tobacco advertising, promotion and sponsorship: Monaco does not ban direct and indirect advertisement. (5) Raise taxes on tobacco: Of the taxes, $67 \%$ is value added and $34 \%$ is excise tax.

(1) Protect people from tobacco smoke: Health care facilities, education facilities, including universities, and government facilities, in Montenegro are completely smoke-free.

Smoking violations consist of fines on the establishment and the patron. A system is in place for citizen complaints and further investigations; however, no funds are dedicated to enforcement. There is no ban on smoking in indoor offices and workplaces, restaurants, cafés, pubs and bars, public transport, and all other indoor public places. (2) Offer help to quit tobacco use: Smoking cessation services are available in some health clinics or other primary care facilities, and the National Health Service/Insurance fully covers its costs. Cessation support for youth is provided by counselling services in all health care centres in Montenegro. No toll-free quit-line or nicotine replacement therapy is available. (3) Warn about the dangers of tobacco: Health warnings are legally mandated to cover $30 \%$ of the front and $40 \%$ of the rear of the principal display area, whereby 16 health warnings are approved by law. They appear on each package and any outside packaging and labelling used in the retail sale and describe the harmful effects of tobacco use on health. Moreover, health warnings rotate on packages and are written in the principal language(s) of the country. The law also mandates font style, font size and colour for package warnings. The warnings include a photograph or graphics. (4) Enforce bans on tobacco advertising, promotion and sponsorship: Montenegro has a ban, through a law adopted in 2004 and last amended in 2011 (5), on most forms of direct and indirect advertising. The law requires fines for violations of these direct and indirect advertising bans. There is no ban on advertising at point of sale, appearance of tobacco products on television and/or in films, or display of tobacco products at point of sale. (5) Raise taxes on tobacco: In Montenegro, a pack of cigarettes costs 1.30 EUR2 (US\$ 1.74$)$, of which $77.89 \%$ is tax $(15.97 \%$ is value added and $61.92 \%$ is excise tax $)^{87}$. 
Republic of In 2016 Moldova adopted the Moldova Ministry of Health Ordinance No. 139 on the Establishment of Counselling and Treatment for Smoking Cessation ${ }^{88}$.

Netherlands Transposition of the TPD is guaranteed by the Tobacco Act (last amended on 1 January 2014) and enforced by a number of Decrees ${ }^{90}$.

Norway The amendment 'Lovvedtak 26 (2016-2017)' to the Norwegian Tobacco Act ensures the implementation of the TPD, as well as the introduction of Plain packaging. Lovvedtak 26 (2016-2017) is implemented on $1 / 4 / 2017$, except for certain measures ${ }^{91}$.

Poland* Act of 22 July 2016 amends the Law on health protection against the consequences of using tobacco and tobacco products. Poland has furthermore adopted Regulation of the Minister of Health of 1 September 2016 on the list of laboratories to verify the maximum level of secreted tar, nicotine and carbon
monoxide in cigarette smoke ${ }^{92}$.
(1) Protect people from tobacco smoke: Health care facilities and education facilities, including universities, in the Republic of Moldova are completely smoke-free. Smoking violations consist of fines on the patron but not on the establishment. A system is in place for citizen complaints and further investigations; however, no funds are dedicated for enforcement. Government facilities, indoor offices and workplaces, restaurants, cafés, pubs and bars, and public transport is not smoke-free. (2) Offer help to quit tobacco use: Smoking cessation services are available in some health clinics or other primary care facilities, and the National Health Service/Insurance fully covers its costs. Nicotine replacement therapy can be purchased over the counter in a pharmacy but is not costcovered, and no toll-free quit-line is available. (3) Warn about the dangers of tobacco: Health warnings are legally mandated to cover $30 \%$ of the front and $40 \%$ of the rear of the principal display area, whereby 14 health warnings are approved by law. They appear on each package, and any outside packaging and labelling used in the retail sale, and describe the harmful effects of tobacco use on health. Moreover, health warnings rotate on packages and are written in the principal language(s) of the country. The law also mandates font style, font size and colour for package warnings. However, the warnings do not include a photograph or graphics. (4) Enforce bans on tobacco advertising, promotion and sponsorship: The Republic of Moldova has a ban, through a law adopted in 2007 that repealed previous laws dated 1997 and 2011, on several forms of direct and indirect advertising. The law does not require fines for violations of these direct and indirect advertising bans. There are no bans on advertising at point of sale, on the internet, in free distribution in mail or other means, promotional discounts or of appearance of tobacco products on television and in films. There is no ban on display of tobacco products at point of sale. (5) Raise taxes on tobacco: In the Republic of Moldova, a pack of cigarettes costs 15 MLD1 (US\$ 1.08), of which $50.67 \%$ is tax $(16.67 \% \text { is value added and } 34.0 \% \text { is excise tax })^{89}$. (1) Protect people from tobacco smoke: The Netherlands has a complete ban on smoking in cafés and restaurants, but with closed, ventilated, designated smoking rooms. There is a total ban on smoking in public transportation, but not in private cars. There is a complete ban on smoking in workplaces and other public places, but with closed, ventilated, designated, smoking rooms. At least 75\% of the workplaces are smoke-free. (2) Warn about the dangers of tobacco: Netherlands has pictorial health warnings on cigarettes and RYO tobacco products covering $51-79 \%$ of the package according to TPD provisions. Health warnings will have to cover $65 \%$ of the front and the back of cigarette and roll-your-own tobacco (RYO) packs following TPD implementation. The Netherlands has not adopted plain packaging. (3) Enforce bans on tobacco advertising, promotion and sponsorship: Netherlands has a ban on tobacco advertising on $\mathrm{tv}$, radio, in cinema, outdoors areas, and printed materials. There is no ban on advertising at point of sales, no ban on display of tobacco products at point of sale. There is a ban on national and international sponsorship and on indirect advertising.

(4) Raise taxes on tobacco: The retail price for cigarettes at weighted-average price was 6,05 EUR or 4,69 EUR to Purchasing Power Standard per capita, as per 1 July $2016^{9}$.

(1) Protect people from tobacco smoke: Norway has a complete ban on smoking in bars and restaurants, public transport and other public places. There is no ban on smoking in private cars. Smoking in the work place is subject to a complete ban, but with closed, ventilated, designated smoking rooms. At least 75\% of the workplaces are smoke-free. (2) Offer help to quit tobacco use: Norway has a national quit-line with counsellors answering at least 30 hours per week. Family doctors are reimbursed for providing brief advice. There is no legal or financial incentive to record smoking status in all medical notes or patient files and no reimbursement of smoking cessation medications. (3) Raise taxes on tobacco: The retail price for a package of Marlboro minus 10\% was 11,07 EUR or 6,79 EUR to Purchasing Power Standard per capita, as per 1 July $2016^{9}$.

(1) Protect people from tobacco smoke: Poland has meaningful restrictions to smoking in bars and restaurants. All means of public transportation are smoke-free. Workplaces are subject to meaningful restrictions on smoking with more than $50 \%$ of the workplaces being smoke-free. The Polish law allows exceptions, for instance for drinking and eating establishments with two or more rooms. (2) Warn about the dangers of tobacco: Poland has pictorial health warnings on cigarettes and RYO tobacco products covering $51.9 \%$ of the package according to TPD provisions. Health warnings will have to cover $65 \%$ of the front and the back of cigarette and roll-your-own tobacco (RYO) packs following TPD implementation. Poland has not adopted plain packaging. (3) Raise taxes on tobacco: The retail price for cigarettes at weighted-average price was 3,13 EUR or 4,54 EUR to Purchasing Power Standard per capita, as per 1 July $2016^{9}$. 
Portugal Portugal adopted Law No. 109/2015 of 26 August 2015, Amending Law No. 37/2007 of 4 August 2007 and Transposing Directive 2014/40/EU (PT) ${ }^{93}$.

Romania In 2016 Romania adopted the Update of the LAW No. 349 of 6 June 2002 on preventing the consumption of tobacco products and combating its effects, which transposes the TPD into national law ${ }^{94}$.
(1) Protect people from tobacco smoke: Public transportation means are subject to a complete smoking ban. Until 2020 smoking areas are still allowed in work places, restaurants, pubs and bars. Meaningful restrictions apply to smoking in bars and restaurants, $50 \%$ are smoke-free. Work places are equally subject to meaningful restrictions to smoking, with more than $50 \%$ of the workplaces being smoke-free. (2) Offer help to quit tobacco use: Portugal has a national quit-line, with counsellors available less than 30 hours per week. There is partial reimbursement of smoking cessation medications. Portugal offers no legal or financial incentives to record smoking status in all medical notes or patient files and no reimbursement to family doctors for providing brief advice. (3) Warn about the dangers of tobacco: Portugal has pictorial health warnings on cigarettes and RYO tobacco products covering $51.9 \%$ of the package according to TPD provisions. Health warnings will have to cover $65 \%$ of the front and the back of cigarette and roll-your-own tobacco (RYO) packs following TPD implementation. Portugal has not adopted plain packaging. (4) Raise taxes on tobacco: The retail price for cigarettes at weighted-average price was 4,29 EUR or 5,57 EUR to Purchasing Power Standard per capita, as per 1 July $2016^{9}$.

(1) Protect people from tobacco smoke: All enclosed public places in Romania are completely smoke-free. Smoking violations consist of fines on the patron but not on the establishment. A system is in place for citizen complaints and further investigations; however, no funds are dedicated for enforcement. (2) Offer help to quit tobacco use: Smoking cessation services are available in some health clinics or other primary care facilities, and the National Health Service/Insurance fully covers its costs. Nicotine replacement therapy can be purchased over the counter in a pharmacy but is not costcovered, and a toll-free quit-line is available. (3) Warn about the dangers of tobacco: Health warnings are legally mandated to cover $30 \%$ of the front and $40 \%$ of the back of the principal display area, whereby 16 health warnings are approved by law. Health warnings will have to cover 65\% of the front and the back of cigarette and roll-your-own tobacco (RYO) packs following TPD implementation. They appear on each package and any outside packaging and labelling used in the retail sale, describe the harmful effects of tobacco use on health and include a photograph or graphics. Moreover, health warnings rotate on packages and are written in the principal language(s) of the country. The law also mandates font style, font size and colour for package warnings. Total tobacco control expenditures, which may include mass media campaign expenditures, amount to US\$ 7 940105 in Romania, which is greater than US\$ 0.10 per capita. (4) Enforce bans on tobacco advertising, promotion and sponsorship: Romania has a ban, through a law adopted in 2004 and last amended in 2008, on several forms of direct and indirect advertising. The law requires fines for violations of these direct and indirect advertising bans. (5) Raise taxes on tobacco: In Romania, a pack of cigarettes costs 14.50 RON1 (US\$ 4.39), of which $75.41 \%$ is $\operatorname{tax}(19.35 \% \text { is value added and } 56.06 \% \text { is excise tax })^{95}$.

(1) Protect people from tobacco smoke: All public places in the Russian Federation are completely smoke-free. Smoking violations incur fines for the patron and the establishment, but no funds are dedicated to enforcement, and no system is in place for citizen complaints and further investigations. (2) Offer help to quit tobacco use: Smoking cessation services are available in some health clinics and other primary care facilities, hospitals and offices of health professionals, with costs fully covered by the National Health Service/Insurance (except for cessation support in hospitals, which is not costcovered). Nicotine replacement therapy can be purchased over the counter in a pharmacy without a prescription, but is not cost-covered. A toll-free quit-line is available. (3) Warn about the dangers of tobacco: Health warnings are legally mandated to cover $30 \%$ of the front and $50 \%$ of the back of the principal display area, with 13 such warnings approved by law. They describe the harmful effects of tobacco use on health and include a photograph or graphic. The law also mandates font size/style and colour for package warnings. The position of health warnings on packages rotates and the messages are written in the principal language(s) of the country. Moreover, the law mandates warnings to appear on each package and any outside packaging and labelling used in retail sale. (4) Enforce bans on tobacco advertising, promotion and sponsorship: Through federal laws on advertising (adopted in 2006, amended in 2013) and tobacco control (adopted in 2013), the Russian Federation has bans in place on all forms of direct and indirect advertising. The law requires fines for violations of these bans ${ }^{96}$. 
Serbia

Slovakia On 1 July 2016 Slovakia adopted Act No. 308/2000 and Act No. 278/2015 on Broadcasting and Retransmission Act and on Amendment to Act No. 195/2000 Coll. on telecommunications. This act installs provisions relating to the advertisement and sponsoring of tobacco products on tv and media ${ }^{98}$. Slovakia further adopted Act No. 89/2016 Z on the manufacture, labelling and sale of tobacco products and related products and on the amendment of certain laws ${ }^{99}$. These acts transpose the TPD into national law.

Slovenia On 24 February 2017 Slovenia adopted the Law on restricting the use of tobacco and related products. Among other measures, this law imposes plain tobacco packaging from 2020. On 5 May 2017, Slovenia adopted Rules on health warnings on tobacco products. These provisions transpose the TPD into national law.
(1) Protect people from tobacco smoke: Health care facilities, education facilities, including universities, government facilities and public transport in Serbia are completely smokefree. Smoking violations consist of fines on the establishment and the patron. Funds are dedicated for enforcement; however, no system is in place for citizen complaints and further investigations. Indoor offices and workplaces, restaurants, cafés, pubs and bars, and all other indoor public places are not completely smoke-free. (2) Offer help to quit tobacco use: Smoking cessation services are available in some health clinics or other primary care facilities, and the National Health Service/Insurance fully covers its costs. Nicotine replacement therapy can be purchased over the counter in a pharmacy but is not cost-covered, and no toll-free quit-line is available. (3) Warn about the dangers of tobacco: Health warnings are legally mandated to cover 30\% of the front and $40 \%$ of the rear of the principal display area, whereby 12 health warnings are approved by law. They describe the harmful effects of tobacco use on health, rotate on packages and are written in the principal language(s) of the country. The law also mandates font style, font size and colour for package warnings. However, the health warnings do not include a photograph or graphics and are not mandated to appear on each package and any outside packaging and labelling used in the retail sale. (4) Enforce bans on tobacco advertising, promotion and sponsorship: Serbia has a ban, through a law adopted in 2005, on several forms of direct and indirect advertising. The law requires fines for violations of these direct and indirect advertising bans. There are no bans on advertising at point of sale, advertising via nontobacco products identified with tobacco brand names, appearance of tobacco products on television and/or in films, sponsored events, tobacco products display at point of sale. (5) Raise taxes on tobacco: In Serbia, a pack of cigarettes costs 170 RSD1 (US\$ 1.95), of which $77.92 \%$ is tax (16.67\% is value-added and $61.25 \%$ is excise tax $)^{97}$.

(1) Protect people from tobacco smoke: Slovakia has meaningful restrictions to smoking in bars and restaurants, with $50 \%$ of bars and restaurants being smoke-free. There is a ban on smoking in some public transportation means and meaningful restrictions for smoking in workplaces more than 50\% of the workplaces are smoke-free. (2) Offer help to quit tobacco use: No toll-free quit-line is available. (3) Warn about the dangers of tobacco: Slovakia has pictorial health warnings on cigarettes and RYO tobacco products covering $5179 \%$ of the package according to TPD provisions. Health warnings will have to cover $65 \%$ of the front and the back of cigarette and roll-your-own tobacco (RYO) packs following TPD implementation. Slovakia has not adopted plain packaging. (4) Enforce bans on tobacco advertising, promotion and sponsorship: Slovakia has a ban on advertising of tobacco products on $\mathrm{tv}$, radio, in cinema, outdoor areas, printed material, national and international sponsorship, and indirect advertisement. There is no ban on advertising of tobacco products at points of sale or display of tobacco products at points of sale. (5) Raise taxes on tobacco: The retail price for cigarettes at weighted-average price was 3,06 EUR or 3,69 EUR to Purchasing Power Standard per capita, as per 1 July 2016. Of the retail price of the most popular price category of tobacco product consists of $79 \%$ taxes levied in a combination of specific and ad valorem taxes ${ }^{9}$.

(1) Protect people from tobacco smoke: Slovenia has a complete ban on smoking in cafés and restaurants, but with closed, ventilated, designated smoking rooms. All public transport is smoke-free and smoking in cars in presence of minors is banned as of February 2017. Workplaces are subject to a complete ban on smoking, but with closed, ventilated, designated smoking rooms. At least 75\% of the workplaces are smoke-free. (2) Offer help to quit tobacco use: Slovenia has a national quit-line, with counsellors available less than 30 hours per week. There are no legal or financial incentives to record smoking status in all medical notes or patient files. Family doctors are not reimbursed for providing brief advice and there is no reimbursement of smoking cessation medications. (3) Raise taxes on tobacco: The retail price for cigarettes at weighted-average price was 3,51 EUR or 4,23 EUR to Purchasing Power Standard per capita, as per 1 July $2016^{9}$. Of the retail price of the most popular price category of tobacco product consists of $79,81 \%$ taxes levied in a combination of specific and ad valorem taxes ${ }^{100}$. 
Spain

Sweden

Switzerland In 2012 Switzerland adopted the Ordinance on Tobacco Products and Products Containing Tobacco ByProducts Intended for Smoking (817.06) (as amended October 1 $2012)^{107}$. components as well as additives in certain tobacco products (HSLF-FS on changes to the regulations (HSLF-FS 2016:46) on the design and positioning of health products (HSLF-FS 2016:77) on 11 July 2017, and a number of legislative measures in view of transposing the EU TPD adopted on 20 May $2017^{105}$.
(1) Protect people from tobacco smoke: Spain has a complete ban on smoking in cafes and restaurants, but with closed, ventilated, designated smoking rooms under very strict rules.

There is a ban on smoking in all public transportation means and a complete ban on smoking in the workplace without exceptions. There is no ban on smoking in private cars. (2) Offer help to quit tobacco use: Spain does not have a national quit-line. Some regions have local quit-lines. Smoking cessation medications are not reimbursed, and family doctors are not reimbursed for providing brief advice. Smoking cessation medications are reimbursed only in two Spanish regions. There are no legal or financial incentives to record smoking status in all medical notes or patient files. (3) Warn about the dangers of tobacco: Spain has pictorial health warnings that cover $65 \%$ of the front and the back of cigarette and roll-your-own tobacco (RYO) packs following TPD implementation. (4) Enforce bans on tobacco advertising, promotion and sponsorship: Spain has a ban on tobacco advertising on television, radio, in cinema, outdoor advertising, printed material, international and national sponsorship and indirect advertising. Nevertheless, in some TV series there are frequently actors smoking. There is no ban on advertising at point of sales and no display ban. (5) Raise taxes on tobacco: The retail price for cigarettes at weighted average price was 4,44 EUR or 4,83 EUR to Purchasing Power Standard per capita, as per 1 July $2016^{9}$. Of the retail price of the most popular price category of tobacco product consists of 79,9\% taxes levied in a combination of specific and ad valorem taxes ${ }^{103}$.

(1) Protect people from tobacco smoke: Sweden has a complete ban, but with closed, ventilated, designated smoking rooms. All public transportation means are smoke-free, and workplaces are subject to a complete ban on smoking but with closed, ventilated, designated smoking rooms, leaving at least 75\% of workplaces smoke-free. (2) Offer help to quit tobacco use: Sweden has a national quit-line with counsellors available more than 30 hours per week. Cessation medication is partially reimbursed and family doctors are reimbursed for providing brief advice. There are no legal or financial incentives to record smoking status in all medical notes or patient files. (3) Warn about the dangers of tobacco: Sweden has pictorial health warnings on cigarettes and RYO tobacco products covering $65 \%$ of the front and the back of the packs following TPD implementation. Sweden has not adopted plain packaging. (4) Raise taxes on tobacco: The retail price for cigarettes at weighted-average price was 5,59 EUR or 4,54 EUR to Purchasing Power Standard per capita, as per 1 July $2016^{\circ}$. Of the retail price of the most popular price category of tobacco product consists of $78 \%$ taxes levied in a combination of specific and ad valorem taxes ${ }^{106}$. 2016:96) ${ }^{104}$. Further achievements concern the adoption of the Order warnings on packaging of tobacco

$\begin{array}{ll}\text { Switzerland } & \text { In } 2012 \text { Switzerland adopted } \\ \text { the Ordinance on Tobacco } \\ \text { Products and Products } \\ \text { Containing Tobacco By- } \\ \text { Products Intended for Smoking } \\ (817.06) \text { (as amended October 1, } \\ \text { 2012) }\end{array}$

(1) Protect people from tobacco smoke: Legislation of smoking in bars of restaurants is a responsibility of the cantons. A majority of the cantons apply smoke-free legislation in bars and restaurants. In general bars and restaurants are subject to meaningful restrictions and $50 \%$ or bars and restaurants are smoke-free. All public transportation means are smoke-free, and workplaces are subject to meaningful restrictions, with more than $50 \%$ being smoke-free. There is no ban on smoking in private cars. (2) Offer help to quit tobacco use: Switzerland has a quit-line, with counsellors available more than 30 hours per week. There is partial reimbursement of cessation medications and reimbursement of family doctors for giving brief advice. (3) Warn about the dangers of tobacco: Switzerland has pictorial health warnings on cigarettes and RYO tobacco products covering 5179\% of the package. Switzerland has not adopted plain packaging. (4) Enforce bans on tobacco advertising, promotion and sponsorship: Switzerland has a ban on tobacco advertising on tv and radio. The country has no ban on tobacco advertising in cinema, outdoor areas, point of sales, display of tobacco products at point of sale, national and international sponsorship or indirect advertising. (5) Raise taxes on tobacco: The retail price $-10 \%$ for a package of Marlboro in Switzerland was 6,77 EUR or 4,18 EUR to Purchasing Power Standard per capita, as per 1 July $2016^{9}$. 
Tajikistan On 26 July 2014, Tajikistan adopted the Code of Administrative Offenses ${ }^{108}$.

The former

Yugoslav

In 2010, FYROM adopted

the Law on Protection from

Macedonia 2010) ${ }^{110}$.

(FYROM)
(1) Protect people from tobacco smoke: No indoor public places in Tajikistan are completely smoke-free. Under current legislation, smoking is prohibited in health-care, government and education facilities, including universities, and on public transport (except in designated smoking areas). Smoking violations incur fines for the establishment and patron. A system is in place for citizen complaints and further investigations, but no funds are dedicated to enforcement. (2) Offer help to quit tobacco use: Smoking cessation services and toll-free quit-line are not available in Tajikistan. Nicotine replacement therapy is available and sold legally in the country. (3) Warn about the dangers of tobacco: The law mandates that health warnings appear on tobacco packages, but does not specify the percentage of the principal display areas of the package that must be covered by the warnings. The law does not mandate specific health warnings and does not specify health warning characteristics. There is no ban on advertising at point of sale, no ban on advertising on the internet, no free distribution in mail or through other means, promotional discounts, non-tobacco products identified with tobacco brand names, appearance of tobacco products on television and/or in films, tobacco products display at point of sale. (4) Enforce bans on tobacco advertising, promotion and sponsorship: Through a law adopted in 2003, Tajikistan has bans in place on some forms of direct and indirect advertising. The law requires fines for violations of these bans. (5) Raise taxes on tobacco: A pack of cigarettes in Tajikistan costs 5 TJS1 (US\$ 1.01), of which $25.88 \%$ is $\operatorname{tax}(15.25 \%$ is value-added tax, 2.66\% excise tax, and 7.97\% import duty) ${ }^{109}$.

(1) Monitor tobacco use for both adults and youth: FYROM only monitors prevalence data for either adults or youth, but not for both. (2) Protect people from tobacco smoke:

Almost all enclosed public places in FYROM are completely smoke-free. Smoking violations consist of fines on the establishment and the patron. However, no funds are dedicated for enforcement, and no system is in place for citizen complaints and further investigations. (3) Offer help to quit tobacco use: Smoking cessation services are available of which some are cost-covered, but FYROM only provides cessation support in some health clinics or other primary care facilities. Nicotine replacement therapy can be purchased over the counter in a pharmacy but is not cost-covered, and no toll-free quit-line is available. (4) Warn about the dangers of tobacco: Health warnings are legally mandated to cover $30 \%$ of the front and $40 \%$ of the back of the principal display area, whereby 16 health warnings are approved by law. They appear on each package and any outside packaging and labelling used in the retail sale, describe the harmful effects of tobacco use on health and include a photograph or graphics. Moreover, health warnings rotate on packages and are written in the principal language(s) of the country. The law also mandates font style, font size and colour for package warnings. (5) Enforce bans on tobacco advertising, promotion and sponsorship: The FYROM has a ban, through a law adopted in 1995 and amended many times since then (last amendment was in 2010), on most forms of direct and indirect advertising. The law requires fines for violations of these direct and indirect advertising bans. There is no ban on tobacco advertising through free distribution in mail or through other means, on appearance of tobacco products on television and/or in films, nor on tobacco products display at point of sale. (6) Raise taxes on tobacco: In FYROM, a pack of cigarettes costs 60.00 MKD1 (US\$ 1.31), of which $72.59 \%$ is $\operatorname{tax}(15.25 \%$ is value added and $57.33 \%$ is excise tax $)^{111}$. 
Turkey In 2015 Turkey adopted Decision (1) Protect people from tobacco smoke: First smoke-free implementation at some public No. 2015-8353 Adjusting Tax Rates, Council Decision No. places (health, education, sports and cultural facilities and public transport) was in 1996 and the law was amended in 2008. Cafés and restaurants are subject to a complete ban, 9010 on Amending the Council but with closed, ventilated, designated smoking rooms. Compliance is however insufficient Decision Concerning the Assessment of Data Included in cafés, coffee or teahouses. There is a ban on smoking in all public transportation means and a full ban on smoking in workplaces with no exceptions. There is no ban on smoking on the Ingredients Declaration and Toxicology Data Tables and the National tobacco control program action plan (2015in private cars. (2) Offer help to quit tobacco use: Smoking cessation counselling and treatment has been provided for years, all three medicines (Bupropion, Varenicline and NRT preparations) are available since 2010 or 2011. Total of 415 smoking cessation centres provide cessation service and toll-free quit-line is in operation since 2010 on a 24-hour 2018). In 2012, Turkey amended basis. Turkey has no legal or financial incentives to record smoking status in all medical the tobacco control law. The notes or patient files, no reimbursement of family doctors for providing brief advice and no amendment brought Turkey reimbursement of cessation medications. (3) Warn about the dangers of tobacco: Turkey fully in line with all six MPOWER has pictorial health warnings on cigarettes and RYO tobacco products covering $51-79 \%$ measures, being the first country to reach the highest level of achievement in all six $\operatorname{areas}^{112}$. of the package. Turkey has not adopted plain packaging. (4) Enforce bans on tobacco advertising, promotion and sponsorship: Advertisement and promotion was banned in 1996 by the Tobacco Control Law and sponsorship was banned in 2012 through amendment of the Law. Turkey has bans on tobacco advertising on television, radio, in cinema, outdoors areas, printed material and international sponsorship. There is no ban on advertising at point of sale, display of tobacco products at point of sales or indirect advertising. (5) Article 6. Raise taxes on tobacco: Tax and price increases were done several times; however, cigarette prices are still low (3.3EUR highest, 2.5EUR most popular) compared to most of the European countries. The retail price for cigarettes at weighted-average price in Turkey was 3,21 EUR or 5,81 EUR to Purchasing Power Standard per capita, as per 1 July $2016^{\circ}$. Of the retail price of the most popular price category of tobacco product consists of $84 \%$ taxes levied in a combination of specific and ad valorem taxes ${ }^{113}$.

Turkmenistan In 2016 Turkmenistan adopted (1) Protect people from tobacco smoke: All enclosed public places are completely smokethe Law on Some Changes and Additions to Some Legislative Acts of Turkmenistan ${ }^{114}$. free in Turkmenistan. Smoking violations incur fines for the patron and the establishment, but no funds are dedicated to enforcement and no system is in place for citizen complaints and further investigations. (2) Offer help to quit tobacco use: Smoking-cessation services are available in most health clinics and other primary care facilities, and in offices of health professionals, with costs fully covered by the National Health Service/Insurance. Nicotine replacement therapy can be purchased over the counter in a pharmacy without a prescription, but is not cost-covered. A toll-free quit-line is available. (3) Warn about the dangers of tobacco: Health warnings are legally mandated to cover $65 \%$ of the front and rear of the principal display area, with 12 such warnings approved by law. They appear on each package and any outside packaging and labelling used in retail sale and describe the harmful effects of tobacco use on health. The law also mandates font size/style and colour for package warnings and states that they must include a photograph or graphic. The position of health warnings on packages rotates and the messages are written in the principal language(s) of the country. (4) Enforce bans on tobacco advertising, promotion and sponsorship: Through a law adopted in 2013, Turkmenistan has bans in place on most forms of direct and indirect advertising. The law requires fines for violations of these bans. Turkmenistan does not have ban on advertising of tobacco products at point of sale or on appearance of tobacco brands on television and/or in films. (5) Raise taxes on tobacco: A pack of cigarettes in Turkmenistan costs 11.65 TMT1 (US\$ 4.09), of which $26.11 \%$ is tax $\left(13.04 \%\right.$ is value-added tax, $12.23 \%$ ad valorem excise tax, and $0.83 \%$ import duty) ${ }^{115}$. 


\section{Ukraine}

In 2012 Ukraine adopted Law No. 4844-VI on Amendment of Certain Laws of Ukraine on Improving Certain Provisions on Limiting Places for Smoking ${ }^{116}$.

\footnotetext{
United In 2016 the UK adopted the

Kingdom Tobacco and Related Products

of Great Regulations 2016 (S.I. 2016 No.

Britain and 507), which transposes many

Northern of the provisions of Directive

Ireland 2014/40/EU (TPD), including

the requirements of health

warnings to be placed on

tobacco product packaging ${ }^{118}$.

Also, the Standardised

Packaging of Tobacco Products Regulations 2015 (S.I. 2015 No. 829) was adopted, requiring plain packaging for packages of cigarettes and hand-rolling tobacco produced on or after 20 May 2016. Products produced before that date could be sold until 20 May $2017^{119}$.
}

(1) Protect people from tobacco smoke: Health-care, government and education facilities, including universities, restaurants, cafes, pubs and bars, and public transport are completely smoke-free in Ukraine. Smoking violations incur fines for the patron and the establishment, but no funds are dedicated to enforcement, and no system is in place for citizen complaints and further investigations. There are no smoking bans on indoor offices and workplaces. (2) Offer help to quit tobacco use: Smoking cessation services are available in some health clinics and other primary care facilities, but costs are not covered by the National Health Service/Insurance. Nicotine replacement therapy can be purchased over the counter in a pharmacy without a prescription, but is not cost-covered. No toll-free quit-line is available. (3) Warn about the dangers of tobacco: Health warnings are legally mandated to cover $50 \%$ of the front and back of the principal display area, with 11 such warnings approved by law. They appear on each package and any outside packaging and labelling used in retail sale and describe the harmful effects of tobacco use on health. The law also mandates font size/ style and colour for package warnings and states that packages must include a photograph or graphic. The position of health warnings on packages rotates and the messages are written in the principal language(s) of the country. (4) Enforce bans on tobacco advertising, promotion and sponsorship: Through a law adopted in 1996 and amended several times since, Ukraine has bans in place on most forms of direct and some forms of indirect advertising. The law requires fines for violations of these bans. There are no bans on advertising of tobacco products on the internet, on non-tobacco products identified with tobacco brand names, on appearance of tobacco brands on television and/or in films and on tobacco products display at point of sale. Ukraine does not have a requirement to present prescribed anti-tobacco advertisements before, during or after the broadcasting or showing of any visual entertainment. (5) Raise taxes on tobacco: A pack of cigarettes in Ukraine costs ${ }^{9}$ UAH1 (US\$ 0.74), of which $74.78 \%$ is tax (16.67\% is value-added tax and $58.11 \%$ excise tax $)^{117}$. (6) Ratify the WHO FCTC Protocol to Eliminate Illicit Trade in Tobacco Products

(1) Offer help to quit tobacco use: The UK offers partial reimbursement of cessation medication $^{120}$. 
Uzbekistan In 2011, Uzbekistan adopted Order No. 311 on Approving of the Health Warnings, Addenda 1-7 to Order No. 311 on Approving of the Health Warnings and Law No. 302 on Limitations of the Distribution and Consumption of Alcohol and Tobacco ${ }^{121}$.
(1) Protect people from tobacco smoke: Public transport is completely smoke-free in Uzbekistan. Smoking is prohibited in all other enclosed public places, except in designated areas and premises for the use of tobacco. Smoking violations incur fines for the patron but not the establishment. No funds are dedicated to enforcement, and no system is in place for citizen complaints and further investigations. No ban on smoking is in place for healthcare facilities, education facilities, universities, government facilities, indoor offices and workplaces, restaurants, cafés, pubs and bars. (2) Offer help to quit tobacco use: Smoking cessation services are available in some health clinics and other primary care facilities, with costs fully covered by the National Health Service/Insurance. Cessation support is also available in some hospitals with costs partially covered. Nicotine replacement therapy can be purchased over the counter in a pharmacy without a prescription, but is not cost-covered. No toll-free quit-line is available. (3) Warn about the dangers of tobacco: Health warnings are legally mandated to cover $40 \%$ of the front and rear of the principal display area, with seven such warnings approved by law. They appear on each package and any outside packaging and labelling used in retail sale and describe the harmful effects of tobacco use on health. The position of health warnings on packages rotates and the messages are written in the principal language(s) of the country. The law does not mandate font size/ style and colour for package warnings, and warnings do not include a photograph or graphic. (4) Enforce bans on tobacco advertising, promotion and sponsorship: Through laws on advertising (adopted in 1998 and amended several times since) and limitation of alcohol and tobacco products (adopted in 2011), Uzbekistan has bans in place on some forms of direct and indirect advertising. The law does not require fines for violations of these bans. There are no bans on international television and radio, international magazines and newspapers, advertising on the internet, tobacco advertising through promotional discounts, non-tobacco products identified with tobacco brand names, appearance of tobacco brands on television and/or in films nor of tobacco products display at point of sale $^{122}$.

\section{REFERENCES}

1. European Commission DG Health and Food Safety. http://ec.europa.eu/health/tobacco/policy/index_ en.htm. Accessed June, 2017.

2. World Health Organization Europe. Data and Statistics. http://www.euro.who.int/en/health-topics/diseaseprevention/tobacco/data-and-statistics. Accessed June, 2017.

3. United Nations Treaty Collection. WHO Framework Convention on Tobacco Control. https://treaties. un.org/pages/ViewDetails.aspx?src=TREATY\&mtdsg_ no=IX-4\&chapter=9\&clang=_en. Accessed June, 2017.

4. Directive 2014/40/EU of the European Parliament and of the Council of 3 April 2014 on the approximation of the laws, regulations and administrative provisions of the Member States concerning the manufacture, presentation and sale of tobacco and related products and repealing Directive 2001/37/EC, OJ 2014 L 127/1. 2001.

5. World Health Organization. The WHO Framework Convention on Tobacco Control: an overview. http:// www.who.int/fctc/about/WHO_FCTC_summary_ January2015.pdf?ua=1. Accessed June, 2017.

6. World Health Organization. Guidelines for implementation of the WHO FCTC. http://www. who.int/fctc/guidelines/adopted/guidel_2011/en/. Accessed June, 2017.

7. World Health Organization. Tobacco Free Initiative. Mpower. http://www.who.int/tobacco/mpower/en/.
Accessed June, 2017.

8. European Commission. Memo-Questions \& answers: New rules for tobacco products. http://europa.eu/ rapid/press-release_MEMO-14-134_en.htm. Accessed June, 2017.

9. European Network for Smoking and Tobacco Prevention. http://ensp.org/. Accessed June, 2017.

10. European Respiratory Society. https://www.ersnet. org/. Accessed June, 2017.

11. World Health Organization. FCTC Implementation Database. http://apps.who.int/fctc/implementation/ database/. Accessed June, 2017.

12. World Health Organization. Reporting instrument of the WHO Framework Convention on Tobacco Control. http://www.who.int/fctc/reporting/EN_core_ questionnaire_v2016.pdf?ua=1. Accessed June, 2017.

13. World Health Organization. WHO Framework Convention on Tobacco Control. Additional questions on the use of implementation guidelines by the Parties. http://www.who.int/fctc/reporting/additionalquestions_2016_EN.pdf?ua=1. Accessed June, 2017.

14. WHO Framework Convention on Tobacco Control. Good practices in data collection, preparation and submission of FCTC implementation reports. http:// www.who.int/entity/fctc/reporting/reporting-goodpractices-who-fctc.pdf?ua=1. Accessed June, 2017.

15. Campaign for Tobacco Free Kids. Tobacco Control Laws. About This Project. http://www.tobaccocontrollaws. org/learn-more/about/. Accessed June, 2017. 
16. European Network for Smoking and Tobacco Prevention. ENSP Full Members. http://ensp.org/fullmembers/. Accessed June, 2017.

17. Joossens L, Raw M. The Tobacco Control Scale 2016 in Europe. http://www.tobaccocontrolscale.org/wpcontent/uploads/2017/03/TCS-2016-in-EuropeCOMPLETE-LoRes.pdf. Accessed June, 2017.

18. Joossens L, Raw M. The Tobacco Control Scale: a new scale to measure country activity. Tobacco Control. 2006; 15:247-253.

19. Dubray, J, Schwartz, R, Chaiton, M, O'Connor, S, Cohen JE. The effect of MPOWER on smoking prevalence. Tob Control. 2015;24:540-542. doi: 10.1136/tobaccocontrol-2014-051834

20. Anderson CL, Becher H, Winkler V. Tobacco control progress in low and middle income countries in comparison to high income countries. Int J Environ Res Public Health. 2016;13(10):E1039.

21. Puska P. WHO FCTC as a pioneering and learning instrument: Comment on "The legal strength of international health instruments - what it brings to global health governance?" Int J Health Policy Manag. 2018;7(1):75-77. doi:10.15171/ijhpm.2017.63

22. Gilmore AB, Fooks G, Drope J, Bialous SA, Jackson RR. Exposing and addressing tobacco industry conduct in low-income and middle-income countries. Lancet. 2015;385:1029-1043.

23. Uang R, Hiilamo H, Glantz SA. Accelerated Adoption of Smoke-Free Laws After Ratification of the World Health Organization Framework Convention on Tobacco Control. American Journal of Public Health. 2016;106(1):166-171. doi:10.2105/AJPH.2015.302872.

24. WHO Framework Convention on Tobacco Control. 2016 global progress report of the implementation of the WHO Framework Convention on Tobacco Control. Geneva: World Health Organization; 2016.

25. WHO Tobacco Control Fact Sheet: Albania. http://www. euro.who.int/_data/assets/pdf_file/0010/312589/ Tobacco-control-fact-sheetAlbania.pdf. Accessed June, 2017.

26. Butlletí Oficial del Principat d'Andorra Núm. 27 - Any 24 - 13.6.2012. Llei 7/2012, del 17 de maig, de protecció contra el tabaquisme passiu ambiental. http://data.euro. who.int/tobacco/Repository/AD/Andorra_Law\%20 $7 \% 20$ on $\% 20$ protection $\% 20$ from $\% 20$ second $\% 20$ hand\%20smoke_2012_ov.pdf. Accessed June, 2017.

27. WHO report on the global epidemic: Andorra 2015. http://www.who.int/tobacco/surveillance/policy/ country_profile/and.pdf. Accessed June, 2017.

28. Law Of The Republic Of Armenia On Restrictions On The Sale, Consumption, And Use Of Tobacco. http:// www.tobaccocontrollaws.org/files/live/Armenia/ Armenia \%20-\%20Law\%20on\%20Restrictions \%20 of $\% 20$ Sale $\% 2 \mathrm{C} \% 20$ Consumption $\% 2 \mathrm{C} \% 20$ and $\% 20$ Use. pdf. Accessed June, 2017.
29. WHO Tobacco Control Fact Sheet: Armenia. http://www.euro.who.int/__data/assets/pdf_ file/0008/337418/Tobacco-Control-FactSheetArmenia.pdf?ua=1. Accessed June, 2017.

30. Bundesgesetzblatt Für Die Republik Österreich. I Nr. 22/2016. Bundesgesetz Änderung des Tabakgesetzes und des Gesundheits- und Ernährungssicherheitsgesetzes - GESG. https:// www.ris.bka.gv.at/Dokumente/B gblAuth/ BGBLA_2016_I_22/BGBLA_2016_I_22.pdf. Accessed June, 2017.

31. Austrian Council on Smoking and Health. Kurt Aigner.

32. WHO Tobacco Control Fact Sheet: Azerbaijan. http://www.euro.who.int/__data/assets/pdf_ file/0009/337428/Tobacco-Control-FactSheetAzerbaijan.pdf?ua=1. Accessed June, 2017.

33. Decision No.18 of the Eurasian Economic Commission dated March 17, 2016. https://docs.eaeunion.org/docs/ en-us/01010143/cncd_27042016_18. Accessed June, 2017.

34. WHO Tobacco Control Fact Sheet: Belarus. http://www. euro.who.int/_data/assets/pdf_file/0010/337429/ Tobacco-Control-FactSheet-Belarus.pdf?ua $=1$. Accessed June, 2017.

35. Belgisch Staatsblad - 0/03.2016 - Moniteur Belge. Arrêté royal relatif à la fabrication et à la mise dans le commerce des cigarettes électroniques. https://www. health.belgium.be/sites/default/files/uploads/fields/ fpshealth_theme_file/2016_10_28_ar_ecigarette_2. pdf. Accessed June, 2017.

36. Belgisch Staatsblad - 03/03.2016 - Moniteur Belge. Arrêté royal portant exécution de l'article 133, alinéa 2 , de la loi du 22 mai 2003 portant organisation du budget et de la comptabilité de l'Etat fédérale. https://www. health.belgium.be/sites/default/files/uploads/fields/ fpshealth_theme_file/2016-02-05_ar_produits_tabac. pdf. Accessed June, 2017.

37. WHO Tobacco Control Fact Sheet: Bosnia and Herzegovina. http://www.euro.who.int/__data/ assets/pdf_file/0012/312600/Tobacco-control-factsheetBosniaHerzegovina.pdf?ua=1. Accessed June, 2017

38. National Assembly Bulgaria. Law on Amending and Supplementing the Law on Tobacco and Tobacco Products DECREE No 89. http://www. tobaccocontrollaws.org/files/live/Bulgaria/ Bulgaria\%20-\%20Decree\%20No.\%2089_2016\%20 Amd\%27ing\%20Law\%20on\%20Tobacco\%20Products. pdf. Accessed June, 2017.

39. WHO Tobacco Control Fact Sheet: Bulgaria. http://www.euro.who.int/__data/assets/pdf_ file/0003/312591/Tobacco-control-fact-sheetBulgaria. pdf?ua=1. Accessed June, 2017.

40. Croatian Parliament. NN 45/2017, Law on Restricting Use of Tobacco and Related Products.

41. Health Protection (Control of Smoking) Law 2017. 
Cyprus Gazette. March 13, 2017;4592:00217-00236.

42. Health Protection (Tobacco Control) Regulations of 2017. Cyprus Gazette. March 13, 2017;5003:0075400814.

43. Senat PCR. Act on Protection from the Harmful Effects of Addictive Substances. http://senat.cz/xqw/xervlet/ pssenat $/$ htmlhled?action $=$ doc\&value $=82464$. Accessed June, 2017.

44. SBíRKA ZÁKONU GESKÁ REPUBLIKA. Decree No. 37/2017 on Electronic Cigarettes, Refill Containers and Herbal Products for Smoking. http://www. tobaccocontrollaws.org/files/live/Czech\%20Republic/ Czech\%20Republic\%20-\%20Decree\%20No.\%20 37_2017\%20-\%20national.pdf. Accessed June, 2017.

45. Zakony pro lidi. Decree No. 261/2016 Decree on tobacco products. http://www.zakonyprolidi.cz/ cs/2016-261. Accessed June, 2017.

46. United Nations Treaty Collection. Protocol to Eliminate Illicit Trade in Tobacco Products Stats as at 6/7/2017. https://treaties.un.org/Pages/ ViewDetails.aspx?src $=$ TREATY\&mtdsg_no $=I X-4-$ a\&chapter $=9 \&$ clang=_en. Accessed June, 2017.

47. Ministry of Health, Journal no.: 1601105. Act no 608 of 07/06/2016 (Current), Government dept. http:// www.tobaccocontrollaws.org/files/live/Denmark/ Denmark\%20-\%20Act\%20No.\%20608.pdf. Accessed June, 2017.

48. Legislation Bulletin A. Electronic cigarettes etc. http:// www.tobaccocontrollaws.org/files/live/Denmark/ Denmark\%20-\%20Act\%20No.\%20426.pdf. Published May 19, 2016. Accessed June, 2017.

49. Danish Cancer Society. Niels Them Kjaer.

50. Riigi Teataja. The Act to Amend the Tobacco. https:// www.riigiteataja.ee/akt/108032016001. Accessed June, 2017.

51. Riigikogu. The Tobacco Act. http://www. tobaccocontrollaws.org/files/live/Estonia/Estonia\%2020 Tobacco $\% 20$ Act $\% 20 \% 28$ as $\% 20$ amended $\% 29$.pdf. Accessed June, 2017.

52. Tobacco-free Estonia. Enn Toom.

53. WHO FCTC Implementation Database: Estonia 2016. http://apps.who.int/WHO FCTC/implementation/ database/sites/implementation/files/documents/ reports/denmark_2016_report.pdf. Accessed June, 2017.

54. Sosiaali- ja terveysministeriö.Tobakslag. Helsingfors, Finland, June 2016. http://stm.fi/ documents/1271139/2964933/Tobakslagen.pdf. Accessed June, 2017.

55. Legi France. Code de la santé publique. Version consolidée au 23 mai 2017 . https://www. legifrance.gouv.fr/affichCode.do;jsessionid= DEFE 794620 E 116 B 33835230 D 5 C 4 F 8 F 00 . tpdila23v_3?cidTexte=LEGITEXT000006072665. Accessed June, 2017.
56. FCTC Implementation Database: France 2016. http:// apps.who.int/fctc/implementation/database/parties/ France\#. Accessed June, 2017.

57. Assemblée nationale. PLFSS 2018 - Annexe 10. http:// www.assemblee-nationale.fr/15/projets/pl0269-ei.asp. Accessed June, 2017.

58. Legislative Herald of Georgia. Law of Georgia On introduction of amendments to the Advertising Law. Document number 860-II's. 17/05/2017. https:// matsne.gov.ge $/ \mathrm{ka} /$ document/view $/ 3676238$. Accessed June, 2017.

59. Legislative Herald of Georgia. Law of Georgia of the Administrative Code Amendments. Document number 861-II's. 17/05/2017. https://matsne.gov.ge/ka/ document/view/3677550. Accessed June, 2017.

60. WHO Tobacco Control Fact Sheet: Georgia. http://www.euro.who.int/_data/assets/pdf file/0020/337430/Tobacco-Control-FactSheetGeorgia.pdf?ua=1. Accessed June, 2017.

61. Bundesministerium für Ernährung und Landwirtschaft. Schutz vor den Gefahren des Tabakkonsums, Bundesminiserium für Ernährung und Landwirtschaft. March 2017. http://www.bmel. de/DE/Ernaehrung/Gesundheit/NichtRauchen/_ Texte/EUTabakproduktrichtlinieNeuordnung2014. html?nn=430496. Accessed June, 2017.

62. Government Gazette Of The Hellenic Republic. September 20, 2016; Law No. 4419, Issue No. 174. First Issue. http://www.tobaccocontrollaws.org/files/live/ Greece/Greece\%20-\%20Law\%20No.\%20 4419.pdf. Accessed June, 2017.

63. FCTC Implementation Database: Greece 2016. http:// apps.who.int/fctc/implementation/database/parties/ Greece\#. Accessed June, 2017.

64. Government regulation 239/2016 (16 August) on the amendment of government regulation $39 / 2013$ ( 14 February) on the detailed rules of production, distribution and control of tobacco products, the combined warnings and the application of health protection fines. Hungarian Official Journal. 2016;(118). http:// www.magyarkozlony.hu/dokumentumok/ 2 da534225ced 907 f63e73ebef 84 fa62923926ad7/ megtekintes. Accessed June, 2017.

65. WHO FCTC Implementation Database: Hungary 2016. http://apps.who.int/fctc/implementation/database/ parties/Hungary\#. Accessed June, 2017.

66. WHO FCTC Implementation Database: Iceland 2016. Available from: http://apps.who.int/WHOFCTC/ implementation/database/sites/implementation/ files/documents/reports/Iceland_2016_report.pdf. Accessed June, 2017.

67. Public Health (Standardised Packaging of Tobacco) Act 2015. http://www.tobaccocontrollaws.org/legislation/ country/ireland/laws/desc. Accessed June, 2017. 
68. European Union (Manufacture, Presentation and Sale of Tobacco and Related Products) Regulations 2016 (S.I. No. 271 of 2016). http://www.tobaccocontrollaws.org/ legislation/country/ireland/laws/desc. Accessed June, 2017.

69. WHO FCTC Implementation Database: Ireland 2016. http://apps.who.int/fctc/implementation/database/ parties/Ireland\#. Accessed June, 2017.

70. WHO Tobacco Control Fact Sheet: Israel. http://www. euro.who.int/_data/assets/pdf_file/0010/312598/ Tobacco-control-fact-sheetIsraele.pdf?ua=1. Accessed June, 2017.

71. LEGISLATIVE DECREE 12 January 2016, no. 6: Implementation of Directive 2014/40/EU on streamlining the legislative, regulatory and administrative provisions of the member states regarding the processing, presentation and sale of tobacco products and related products, which replaces directive 2001/37/EC. (16G00009). Official Gazette Italy. January 18, 2016;13 http://www.gazzettaufficiale. it/eli/id/2016/01/18/16G00009/sg. Accessed June, 2017.

72. WHO FCTC Implementation Database: Italy 2016. http://apps.who.int/WHO FCTC/implementation/ database/sites/implementation/files/documents/ reports/italy_2016_report.pdf. Accessed June, 2017.

73. WHO Tobacco Control Fact Sheet: Kazakhstan. http://www.euro.who.int/__data/assets/pdf_ file/0003/337431/Tobacco-Control-FactSheetKazakhstan.pdf?ua=1. Accessed June, 2017.

74. WHO Tobacco Control Fact Sheet: Kyrgyzstan. http://www.euro.who.int/__data/assets/pdf_ file/0004/337432/Tobacco-Control-FactSheetKyrgyzstan.pdf?ua=1. Accessed June, 2017.

75. Cabinet of Ministers No. 440 in Riga on 5 July 2016 (prot. No. $33 \S 17$ ). Procedures for providing and processing information on tobacco products, herbal smoking products, electronic cigarettes and the filling vials. https://likumi.lv/doc.php?id=283435. Accessed June, 2017.

76. Cabinet of Ministers No. 306 in Riga on 17 May 2016 (prot. No. $23 \S 22$ ). Rules on the requirements for packages deployable warnings about the health effects. https://likumi.lv/ta/id/282235noteikumi-par-prasibam-uz-iepakojumiemizvietojamiembridinajumiem-par-ietekmi-uz-veselibu. Accessed June, 2017.

77. The Legislation Of The Republic Of Latvia. Law on Tobacco products, herbal smoking products, electronic smoking devices and the fluid movement of law. Passed 20/05/2016. https://likumi.lv/ta/id/282077tabakas-izstradajumu-augu-smekesanas-produktuelektronisko-smekesanas-iericu-un-to-skidrumuaprites-likums. Accessed June, 2017.

78. The Government of the Republic of Lithuania.
Resolution No. 958 Regarding the Amendment of Resolution No. 200 of February 23, 2004 "On Authorizing the Implementation of the Law on the Control of Tobacco, Tobacco Products and Associated Products". https://www.e-tar.lt/portal/lt/ legalAct/1a733360864d11 e6b969d7ae07280e89. Accessed June, 2017.

79. The Government of the Republic of Lithuania. Order No. 4-486 Regarding the Amendment of Order No. 4-609 of September 29, 2015. https://www.e-tar.lt/portal/ lt/legalAct/33fd09104fd811 e6b72ff16034f7f796. Accessed June, 2017.

80. FCTC Implementation Database: Lithuania 2016. http://apps.who.int/WHO FCTC/implementation/ database/sites/implementation/files/documents/ reports/final_lithuania_2016_report.pdf. Accessed June, 2017.

81. Règlement grand-ducal du 26 mai 2016 modifiant le règlement grand-ducal du 16 septembre 2003 portant exécution de la loi modifiée du 24 mars 1989 portant restriction de la publicité en faveur du tabac et de ses produits, interdiction de fumer dans certains lieux et interdiction de la mise sur le marché des tabacs à usage oral. Journal officiel du Grand-Duché de Luxembourg. http://legilux.public.lu/eli/etat/leg/rgd/2016/05/26/ n1/jo. Accessed June, 2017.

82. Suppliment tal-Gazzetta tal-Gvern ta' Malta Nru. 19,682. Smoking in Private Vehicles Regulation 2016 (L.N. 386). http://tobaccocontrollaws.org/files/live/ Malta/Malta\%20-\%20Smkg. \%20in\%20Vehicles $\% 20$ Regs\%20-\%20national.pdf. Accessed June, 2017.

83. Tobacco Control Laws. Tobacco (Smoking Control) Act. Manufacture, Presentation and Sale of Tobacco and Related Products Regulations, 2016. http:// tobaccocontrollaws.org/files/live/Malta/Malta\%20 -\%202016\%20Regs.pdf. Accessed June, 2017.

84. WHO FGTG Implementation Database: Malta 2016. http://apps.who.int/WHO FCTC/implementation/ database/sites/implementation/files/documents/ reports/malta_2016_report_0.pdf. Accessed June, 2017.

85. Journal de Monaco du 23 mai 2008. Loi n. $1.346 \mathrm{du}$ 09/05/2008 relative à la protection contre le tabagisme. http://www.legimonaco.mc/305/legismclois.

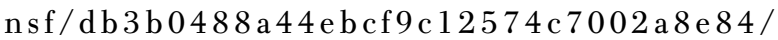
fc54bc60aa0e7be4c125773f003d8f5f!OpenDocument \&Highlight=0,1.346. Accessed June, 2017.

86. Journal de Monaco du 20 juin 2008. Arrêté ministériel n. 2008-295 du 16/06/2008 portant application de la loi $\mathrm{n}^{\circ} 1.346 \mathrm{du} 9$ mai 2008 relative à la protection contre le tabagisme. http://www.legimonaco.mc/305/legismclois. nsf/db3b0488a44ebcf9c12574c7002a8e84/ 9597d0fafcd58c5dc125773f003d929e! OpenDocument \&Highlight=0,2008-295. Accessed June, 2017.

87. WHO Tobacco Control Fact Sheet Montenegro. 
http://www.euro.who.int/__data/assets/pdf_ file/0005/312593/Tobacco-control-fact-sheetMontenegro.pdf?ua=1. Accessed June, 2017.

88. Ministry of Health Ordinance No. 139 on the Establishment of Counseling and Treatment for Smoking Cessation. http://www.tobaccocontrollaws. org/legislation/country/moldova/laws/desc. Accessed June, 2017.

89. WHO Tobacco Control Fact Sheet Moldova. http://www. euro.who.int/_data/assets/pdf_file/0006/312594/ Tobacco-control-fact-sheet-RepofMoldova.pdf?ua $=1$. Accessed June, 2017.

90. Act of March 10, 1988, measures to reduce tobacco use, and in particular to protect the non-smoker. http:// www.tobaccocontrollaws.org/files/live/Netherlands/ Netherlands\%20-\%20 Tobacco\%20Act.pdf. Accessed June, 2017.

91. Stortinget. Endringer i tobakkskadeloven (gjennomføring av direktiv 2014/40/EU og standardiserte tobakkspakninger). https://www. stortinget.no/no/Saker-og-publikasjoner/Saker/ Sak/?p=64493. Accessed June, 2017.

92. The Government Of The Republic Of Poland. Regulation of the Minister of Health of 1 September 2016. On the list of laboratories carrying out the verification of the maximum level of secreted tar, nicotine and carbon monoxide in cigarette smoke. http://dziennikustaw.gov. $\mathrm{pl} / \mathrm{du} / 2016 / 1410 / 1$. Accessed June, 2017.

93. Law No. 109/2015 of August 26, 2015, Amending Law No. 37/2007 of August 4, 2007 and Transposing Directive 2014/40/EU (PT). http:// www.tobaccocontrollaws.org/files/live/Portugal/ Portugal\%20-\%20Law\%20No.\%20109_2015\%20-\%20 national.pdf. Accessed June, 2017.

94. Update of the LAW No. 349 of June 6, 2002. http:// www.tobaccocontrollaws.org/files/live/Romania/ Romania\%20-\%20Law\%20 No.\%20349.pdf. Accessed June, 2017.

95. WHO Tobacco Control Fact Sheet Romania. http://www.euro.who.int/__data/assets/pdf_ file/0007/312595/Tobacco-control-fact-sheetRomania.pdf?ua=1. Accessed June, 2017.

96. WHO Tobacco Control Fact Sheet: Russia. http://www. euro.who.int/_data/assets/pdf_file/0006/337434/ Tobacco-Control-FactSheet-Russian-Federation. pdf?ua=1. Accessed June, 2017.

97. WHO Tobacco Control Fact Sheet: Serbia. http://www. euro.who.int/_data/assets/pdf_file/0008/312596/ Tobacco-control-fact-sheet-Serbia.pdf?ua=1. Accessed June, 2017.

98. 1 July 2016 - Act no. Act No. 308/2000 and Act no. 278/2015 on Broadcasting and Retransmission Act and on Amendment to Act no. 195/2000 Coll. On telecommunications. This act installs provisions relating to the advertisement and sponsoring of tobacco products in tv and media. http://www.zakonypreludi. sk/zz/2000-308. Accessed June, 2017.

99. Act no. 89/2016 Z. z. On the manufacture, labeling and sale of tobacco products and related products and on the amendment of certain laws. http://www.zakonypreludi. sk/zz/2016-89. Accessed June, 2017.

100. WHO FCTC Implementation Database: Slovenia Report 2014. http://apps.who.int/WHO FCTC/ implementation/database/sites/implementation/files/ documents/reports/slovenia_2014_report_final_0.pdf. Accessed June, 2017.

101. Official publication: Boletín Oficial del Estado ( B.O.E ); Number: 138/2017; Publication date: 2017-06-10; Page: 48127-48158

102. Official publication: Boletín Oficial del Estado ( B.O.E ); Number: 210/2017; Publication date: 2017-09-01; Page: $86372-86373$

103. WHO FCTC Implementation Database: Spain Report 2016. http://apps.who.int/fctc/implementation/ database/sites/implementation/files/documents/ reports/spain_2016_report.pdf. Accessed June, 2017.

104. Government of Sweden. Lag om ändring i tobakslagen (1993:581). http://rkrattsdb.gov.se/ SFSdoc/16/160353.PDF. Accessed June, 2017.

105. Government of Sweden. Tobacco Control Laws Sweden. http://www.tobaccocontrollaws.org/legislation/ country/sweden/laws/desc. Accessed June, 2017.

106. WHO FCTC Implementation Database: Sweden Report 2016. http://apps.who.int/WHOFCTC/ implementation/database/sites/implementation/files/ documents/ reports/sweden_2016_report_final.pdf. Accessed June, 2017.

107. Ordinance on tobacco products and products containing tobacco substitutes intended for smoking. http:// www.tobaccocontrollaws.org/legislation/country/ switzerland/law. Accessed June, 2017.

108. Code of Administrative Offenses. http://www. tobaccocontrollaws.org/legislation/country/tajikistan/ laws/desc. Accessed June, 2017.

109. WHO Tobacco Control Fact Sheet: Tajikistan. http://www.euro.who.int/__data/assets/pdf_ file/0007/337435/Tobacco-Control-FactSheetTajikistan.pdf?ua=1. Accessed June, 2017.

110. Law on Protection from Smoking (consolidated through 2010). http://www.tobaccocontrollaws.org/legislation/ country/macedonia/laws/desc.Accessed June, 2017.

111. WHO Tobacco Control Fact Sheet Former Republic of Macedonia. http://www.euro.who.int/en/healthtopics/disease-prevention/tobacco/data-and-statistics/ south-eastern-european-countries-health-impact-oftobacco-control-policies/fact-sheettobacco-control-theformer-yougoslav-republic-of-macedonia . Accessed June, 2017.

112. Decision No 2015-8353 Adjusting Tax Rates. http:// www.resmigazete.gov.tr/eskiler/2016/01/20160101-4. 
pdf. Accessed June, 2017.

113. Council Decision No. 9010. http://www.resmigazete. gov.tr/eskiler/2015/04/20150401-17.htm. Accessed June, 2017.

114. Law on Some Changes and Additions to Some Legislative Acts of Turkmenistan.http://www. tobaccocontrollaws.org/legislation/country/ turkmenistan/laws/desc. Accessed June, 2017.

115. WHO Tobacco Control Fact Sheet: Turkmenistan. http://www.euro.who.int/__data/assets/pdf_ file/0010/337438/Tobacco-Control-FactSheetTurkmenistan.pdf?ua= .Accessed June, 2017.

116. Law No. 4844-VI on Amendment of Certain Laws of Ukraine on Improving Certain Provisions on Limiting Places for Smoking. http://www.tobaccocontrollaws. org/legislation/country/ukraine/laws/desc. Accessed June, 2017.

117. WHO Tobacco Control Fact Sheet: Ukraine. http://www.euro.who.int/__data/assets/pdf_ file/0007/337444/Tobacco-Control-FactSheetUkraine.pdf?ua=1. Accessed June, 2017.

118. The Tobacco and Related Products Regulations 2016. http://www.legislation.gov.uk/uksi/2016/507/ contents/made. Accessed June, 2017.

119. The Standardised Packaging of Tobacco Products Regulations 2015. http://www.legislation.gov.uk/ uksi/2015/829/contents/made. Accessed June, 2017.

120. WHO FCTC Implementation Database UK Report 2016. http://apps.who.int/WHO. Accessed June, 2017.

121. Campaign for Tobacco Free Kids. Country Details for Uzbekistan. http://www.tobaccocontrollaws.org/ legislation/country/uzbekistan/laws/desc. Accessed June, 2017.

122. WHO Tobacco Control Fact Sheet: Uzbekistan. http://www.euro.who.int/_data/assets/pdf_ file/0010/337447/Tobacco-Control-FactSheetUzbekistan.pdf?ua=1. Accessed June, 2017.

CONFLICTS OF INTEREST Marine Faure and Brian Ward are employees of the European Respiratory Society (ERS).The rest of the authors also have completed and submitted an ICMJE form for disclosure of potential conflicts of interest. The authors declare that they have no competing interests, financial or otherwise, related to the current work.

FUNDING

This work was supported by European Commission 3rd Health Programme.

PROVENANCE AND PEER REVIEW

Not commissioned; externally peer reviewed 